\title{
Pepino mosaic virus RNA-Dependent RNA Polymerase POL Domain Is a Hypersensitive Response-Like Elicitor Shared by Necrotic and Mild Isolates
}

\author{
Raquel N. Sempere, Cristina Gómez-Aix, Fabiola Ruíz-Ramón, Pedro Gómez, Beata Hasiów-Jaroszewska, \\ María Amelia Sánchez-Pina, and Miguel A. Aranda
}

First, second, third, fourth, sixth, and seventh authors: Centro de Edafología y Biología Aplicada del Segura (CEBAS), Consejo Superior de Investigaciones Científicas (CSIC), P.O. Box 164, 30100 Espinardo, Murcia, Spain; and fifth author: Institute of Plant Protection-National Research Institute, Department of Virology and Bacteriology, ul. Władysława Węgorka 20, 60-318 Poznán (Poland).

Accepted for publication 6 December 2015.

\begin{abstract}
Sempere, R. N., Gómez-Aix, C., Ruíz-Ramón, F., Gómez, P., HasiówJaroszewska, B., Sánchez-Pina, M. A., and Aranda, M. A. 2016. Pepino mosaic virus RNA-dependent RNA polymerase POL domain is a hypersensitive response-like inducing elicitor shared by necrotic and mild isolates. Phytopathology 106:395-406.

Pepino mosaic virus (PepMV) is an emerging pathogen that represents a serious threat to tomato production worldwide. PepMV-induced diseases manifest with a wide range of symptoms, including systemic necrosis. Our results showed that PepMV accumulation depends on the virus isolate, tomato cultivar, and environmental conditions, and associates with the development of necrosis. Substitution of lysine for glutamic acid at position 67 in the triple gene block 3 (TGB3) protein,

necrosis. Systemic necrosis both in tomato and Nicotiana benthamiana shared hypersensitive response (HR) features, allowing the assessment of the role of different genomic regions on necrosis induction. Overexpression of both TGB3 and the polymerase domain (POL) of the RNA-dependent RNA polymerase (RdRp) resulted in necrosis, although only local expression of POL triggered HR-like symptoms. Our results also indicated that the necrosis-eliciting activity of POL resides in its highly conserved "palm" domain, and that necrosis was jasmonic aciddependent but not salicylic acid-dependent. Altogether, our data suggest that the RdRp-POL domain plays an important role in PepMV necrosis induction, with necrosis development depending on the virus accumulation level, which can be modulated by the nature of TGB3, host genotype and environmental conditions.
\end{abstract} previously described as a necrosis determinant, led to increased virus accumulation and was necessary but not sufficient to induce systemic

Systemic necrosis is the most destructive symptom induced by plant pathogens, often resulting in devastating crop losses in agriculture. In several compatible interactions, a relationship between severe necrotic symptoms and defense responses to virus infection has been reported (Kim et al. 2008; Pallas and García 2011). A significant number of studies have shown that systemic necrosis has hypersensitive response (HR) characteristics, such as the induction of programmed cell death (Dickman et al. 2001; Love et al. 2005; Xu and Roossinck 2000; Xu et al. 2003; Yao et al. 2002). More recently, some works have described that viruses which induce systemic necrosis also code for an elicitor protein, as HR-inducing viruses do (Aguilar et al. 2015; Komatsu et al. 2011; Lim et al. 2014). In this regard, Komatsu et al. (2011) identified a necrosis elicitor in the helicase domain of the RNA-dependent RNA polymerase (RdRp) of Plantago asiatica mosaic virus (PlAMV; genus Potexvirus, family Alphaflexiviridae), a region that was different to the one previously identified in the polymerase domain and reported as an element contributing to systemic necrosis (Ozeki et al. 2006). However, in many instances, although a systemic necrosis determinant has been mapped, it remains unclear whether the determinant alone can elicit necrosis in the same way as an HR elicitor (Burgyán et al. 2000; Ehrenfeld et al. 2005; Hajimorad et al. 2005; Kagiwada et al. 2005; Kim and Palukaitis 1997; Ozeki et al.

Corresponding author: M. A. Aranda; E-mail address: m.aranda@cebas.csic.es

*The $e$-Xtra logo stands for "electronic extra" and indicates that three supplementary figures and one supplementary table are published online.

http://dx.doi.org/10.1094/PHYTO-10-15-0277-R

(C) 2016 The American Phytopathological Society
Additional keywords: potexvirus, Solanum lycopersicum, symptom induction.
2006; Seo et al. 2009), or requires additional factors for necrosis induction.

Pepino mosaic virus (PepMV) is a widespread plant virus that causes a major disease in tomato crops worldwide (Gómez et al. 2012; Hanssen and Thomma 2010; Werkman and Sansford 2010). PepMV belongs to the genus Potexvirus in the family Alphaflexiviridae. The PepMV genome consists of a singlestranded RNA of approximately $6.4 \mathrm{~kb}$ containing five open reading frames, including a replicase gene comprising methyltransferase (MET), helicase (HEL), and polymerase (POL) motifs, a triple gene block (TGB) encoding TGB1, TGB2, and TGB3, involved in viral movement and silencing suppression, and a coat protein $(\mathrm{CP})$ which has a structural role as well as being a silencing suppressor and necessary for viral movement (Aguilar et al. 2002; Mathioudakis et al. 2014; Sempere et al. 2011). The symptoms that PepMV can induce in tomato are highly variable, from mild mosaics to necrosis (Hanssen et al. 2008, 2009, 2011; Hasiów-Jaroszewska et al. 2013; Roggero et al. 1996; Soler and Nuez 2000; Soler-Aleixandre et al. 2005; van der Vlugt et al. 2000). Isolates inducing severe systemic necrosis in tomato have been recently described (Hasiów-Jaroszewska et al. 2009, 2010). The wide range of symptom severity in PepMVinfected tomato plants has been attributed to factors such as the viral strain infecting the plants, plant growth stage at the time of infection, light intensity, temperature fluctuations, nutrition, and tomato cultivar. However, the extent to which these factors influence symptom development has yet to be understood, and whether major differences in symptom display can be attributed solely to the viral isolate is unclear.

Five different genotypes of PepMV have been distinguished based on sequence comparisons, including the EU genotype that initially spread in European tomato crops and the $\mathrm{CH} 2$ genotype 
that later spread epidemically (Gómez et al. 2009; Hanssen and Thomma 2010; Moreno-Pérez et al. 2014). Different isolates have been biologically characterized under experimental conditions, but a strict correlation between the disease phenotype in the field and symptoms observed in experimental conditions has yet to appear (Hanssen et al. 2008, 2009; Hanssen and Thomma 2010). Minor genetic differences between isolates may result in large differences in the nature and severity of symptoms (Duff-Farrier et al. 2015; Hanssen et al. 2009; Hasiów-Jaroszewska et al. 2009, 2013); a mutational analysis has reported that a single amino acid substitution in the TGB3 at position 67 (glutamic acid instead of lysine; K67E) can change a mild strain of PepMV into a necrotic one (Hasiów-Jaroszewska et al. 2011; Hasiów-Jaroszewska and Borodynko 2012), though the underlying mechanisms remain unsolved.

In this work, we have studied the involvement of different factors in PepMV accumulation and necrosis induction, characterizing the necrosis phenotype by biochemical, cellular, and gene expression analyses. Our results suggest that necrosis development is associated with high virus titers, which in turn depend on the virus isolate, tomato cultivar, and environmental conditions. Amino acid substitution K67E in TGB3 appears to be necessary but not sufficient for systemic necrosis induction. We showed that systemic necrosis both in tomato and Nicotiana benthamiana shares HR features. We also mapped in the PepMV genome a necrosis elicitor in a conserved domain of the PepMV RdRp, the POL "palm" domain. Thus, a plausible hypothesis to explain PepMV-necrosis induction is that TGB3 is responsible for determination of necrosis by modulating RdRp-POL domain expression and/or effector activity in PepMV-infected plants.

\section{MATERIALS AND METHODS}

Plasmid constructs. Construction of the binary agroinfectious plasmids including the full-length cDNAs of PepMV-Sp13 (pBPepXL6) and PepMV-PS5 (pBPepPS5) was described previously (Gómez et al. 2009; Sempere et al. 2011). Mutation causing amino acid substitution K67E in TGB3 was generated by PCR-based sitedirected mutagenesis of these plasmids using specific primers as described in Sempere et al. (2011). To generate constructs for transient expression of the different RdRp domains or PepMV proteins, we used pGWB binary vectors (Nakagawa et al. 2007). To generate pGWB2-M (MET domain: amino acids 1 to 327), pGWB2MH (MET-HEL domains: amino acids 1 to 948), pGWB2-POL (polymerase domain: amino acids 915 to 1380), pGWB2-TGB1, and pGWB2-CP, each domain or gene was PCR amplified using the appropriate forward primers including both Gateway BP sites and Kozak sequences and the corresponding reverse primers containing GW BP site using PepMV-Sp13 cDNA as template. Tagged constructs used to monitor protein expression are as described in Mathioudakis et al. (2014). All PCRs were performed using Pyrobest polymerase (Takara), PCR products were cloned in pDonor201 and subcloned in pGWB2 following Invitrogen Gateway procedures. TGB2, TGB3K, and pTGB3E plasmids were constructed using the same protocols as described above but cloned into pGWB8 to fuse the corresponding open reading frame to a His-Tag at the $3^{\prime}$ end. Oligonucleotide primers are described in Supplementary Table S1.

Plant material, virus isolates, and inoculations. Tomato seedlings from six varieties (Beta Lux, Malinowy Ożarowski, and Koneser, from Poland; and Boludo, Moneymaker, and Muchamiel from Spain) were grown under controlled conditions mimicking greenhouse summer (16-h photoperiod, 26 to $28^{\circ} \mathrm{C}$ day, 18 to $20^{\circ} \mathrm{C}$ night) and winter (14-h photoperiod, 21 to $22^{\circ} \mathrm{C}$ day, 15 to $16^{\circ} \mathrm{C}$ night) conditions, as well as in a growth chamber with $16-\mathrm{h}$ photoperiod, 24 to $25^{\circ} \mathrm{C}, 18$ to $20^{\circ} \mathrm{C}$ night. For necrosis characterizations, tomato 'Moneymaker' and $N$. benthamiana plants were grown in a growth chamber at 25 to $26^{\circ} \mathrm{C}$ and $16-\mathrm{h}$ photoperiod. Transgenic $N$. benthamiana plants expressing the SA-degrading enzyme salicylate hydroxylase (NahG plants) or a transgene for silencing of the jasmonic acid perception gene Coronatine insensitive 1 (NbCOIl plants) (García-Marcos et al. 2013) were used together with wild-type controls. Seeds for transgenic $N$. benthamiana were kindly provided by Dr. Tenllado (Departamento de Biología Medioambiental, Centro de Investigaciones Biológicas, CSIC, Spain). Inoculations were performed by rubbing $N$. benthamiana sap from previously agroinfected plants with full-length clones of PepMV-Sp13, PepMV-Sp13/TGB3 ${ }_{\text {K67E, }}$ PepMV-Ch2, or PepMV-PS5/TGB3 ${ }_{\mathrm{K} 67 \mathrm{E}}$ onto the first fully expanded tomato leaf (10 days after sowing) and $N$. benthamiana leaves ( 4 to 5 weeks old). Inoculum was prepared by grinding $10 \mathrm{~g}$ of leaf material in $25 \mathrm{ml}$ of $30 \mathrm{mM}$ potassium phosphate buffer $(\mathrm{pH} 8)$. Agroinfiltration assays were performed as described by Sempere et al. (2011).

RNA extractions and real-time quantitative RT-PCR. All leaves from three tomato plants from each treatment were homogenized by using a Polytron PT 3100 (Kinematica, Lucerne, Switzerland) in $10 \mathrm{mM}$ Tris- $\mathrm{HCl}, 5 \mathrm{mM}$ EDTA (pH 8), and $2 \%$ sodium dodecyl sulfate (TNA). Three biological replicates were processed at 24 days postinoculation (dpi). For $N$. benthamiana, the top three symptomatic leaves from three infected plants were collected and homogenized in TNA. Total RNA was extracted by using Tri-Reagent $(150 \mathrm{mg} / \mathrm{ml})$. RNA concentrations were quantified in a NanoDrop ND-1000 spectrophotometer (Thermo Fisher Scientific, Wilmington, DE), adjusted to $100 \mathrm{ng} / \mathrm{ml}$ and then stored in aliquots at $-80^{\circ} \mathrm{C}$. Accumulation of each PepMV isolate was estimated by measuring viral RNA accumulation by absolute real-time quantitative PCR with an AB7500 System (Applied Biosystems, Foster City, CA) using the Power SYBR Green RNA-to-CT 1-Step Kit (Applied Biosystems) following procedures previously described by Gómez et al. (2009). 9-LOX and $a-D O X-1$ levels were analyzed by relative RT-qPCR using Power SYBR Green PCR master mix following the instructions manual. Prior to RT, the total RNA was treated with DNase I (New England Biolabs, Ipswich, MA) and subsequently purified by phenolchloroform extraction. RT was performed following the transcriptase protocol (Roche Applied Science) using an oligo-dT (16) $_{\text {primer. }}$ Fifty nanograms of cDNA was used in each qPCR reaction. Three independent biological replicates for each treatment were used for RT-qPCR analyses, and the values obtained averaged. The amplification efficiency was determined for each primer pair with a fivefold serial dilution of an RNA sample (100 $\mathrm{ng}$ of RNA/ml) with at least five dilution points. Primers used to analyze oxylipins in $N$. benthamiana are described in García-Marcos et al. (2013). The relative quantification of PCR products was calculated by the comparative $\triangle \triangle C T$ (cycle threshold) method. Transcripts for elongation factor $1 a$ and actin were used as references in RT-qPCR analyses from tomato and $N$. benthamiana samples, respectively. The value obtained for the control was set at 1 and the other data were calculated relative to this value.

Detection of defense-associated responses. The histochemical detection of $\mathrm{H}_{2} \mathrm{O}_{2}$ in tomato and $N$. benthamiana leaves was performed using endogenous peroxidase-dependent in situ histochemical staining as in Díaz-Vivancos et al. (2008). The histochemical detection of $\mathrm{O}_{2}{ }^{-}$was performed by infiltrating leaf quarters directly with nitro blue tetrazolium (NBT) at $0.1 \mathrm{mg} / \mathrm{ml}$ in $25 \mathrm{mM}$ K-HEPES buffer ( $\mathrm{pH}$ 7.6) and incubating at $25^{\circ} \mathrm{C}$ in the dark for $2 \mathrm{~h}$ (Díaz-Vivancos et al. 2008). In both cases, leaves were rinsed in $95 \%$ ( vol/vol) ethanol for $10 \mathrm{~min}$ at $80^{\circ} \mathrm{C}$, mounted under distilled water, and photographed directly using an Olympus SZX PT stereomicroscope.

Light and transmission electron microscopy. For ultrastructural morphological investigations, $1 \mathrm{~mm}^{2}$ tissue squares were processed as in Gosálvez-Bernal et al. (2008). Semithin (1 to $2 \mu \mathrm{m})$ and ultrathin $(500 \mathrm{~nm})$ sections were obtained with a Leica Ultracut 
UCT Microtome and diamond knives. Semithin sections were stained with toluidine blue before examining them with a DMRB Leitz (Leica Microsistemas S.A., Barcelona, Spain) light microscope and photographed with a DC 500 digital camera (Leica Microsistemas S.A.). Ultrathin sections were collected on formvarcoated copper grids and contrasted with $2 \%$ aqueous uranyl acetate and Reynold's lead citrate before studying them with a Phillips Tecnai 12 transmission electron microscope (TEM, $80 \mathrm{Kv}$ ).

Statistical analyses. Viral accumulation analyses were carried out using mixed effects models with restricted maximum likelihood, where PepMV accumulation data were square roottransformed to get a normal distribution, and then, the factors PepMV type, tomato cultivar, and environmental conditions were fitted as three-level fixed effects, with their interactions. The replicated values within each treatment were fitted as a random effect. $F$ tests were used for variance analysis, with a significant $P$ value of 0.05 . All analyses were carried out using JMP v.9 software (SAS; http://www.jmp.com/en_us/home.html).

\section{RESULTS}

Viral accumulation depends on the virus isolate, host genotype, and environmental conditions. We first examined the extent to which different environmental conditions and host genotypes could affect viral RNA accumulation. Plants of six tomato varieties were inoculated with two nonnecrogenic isolates, PepMV-Sp13 (EU-type) (Aguilar et al. 2002) and PepMV-PS5 (CH2-type) (Gómez et al. 2009), and with two necrogenic mutants, PepMV-Sp13/TGB3 ${ }_{\text {K67E }}$ and PepMV-PS5/TGB3 ${ }_{\text {K67E }}$ (Fig. 1A). Environmental conditions were 26 to $28^{\circ} \mathrm{C}$ day, 18 to $20^{\circ} \mathrm{C}$ night, $16 \mathrm{~h}$ light, for condition I, and 21 to $22^{\circ} \mathrm{C}$ day, 15 to $16^{\circ} \mathrm{C}$ night, $8 \mathrm{~h}$ light, for condition II, simulating summer and winter, respectively, in a Northern hemisphere greenhouse of a temperate area. After 24 dpi, PepMV accumulation was remarkably affected by the interaction between isolate type, environmental condition, and tomato cultivar (Fig. $1 \mathrm{~B} ; F_{15,94}=10.20, P<0.001$ ). Specifically, necrogenic isolates accumulated to significantly higher levels than nonnecrogenic isolates (Fig. 1B, note the difference in scale between the upper and lower graphics; main effect of isolate type: $\left.F_{3,94}=187.42, P<0.001\right)$ and environmental condition I increased significantly (twofold) viral accumulation with respect to condition II (Fig. 1B; main effect of environmental condition: $F_{1,94}=34.157$, $P<0.001)$. Each tomato cultivar had a net effect on viral accumulation (Fig. 1B; main effect of tomato cultivar: $F_{5,94}=17.42, P<0.001$ ), with the highest accumulation found for Malinowy Ożarowski, followed by Moneymaker, Koneser, Boludo, Muchamiel, and the lowest for Beta Lux. We then examined the impact of necrosis in all treatments. Necrotic symptoms were only observed in tomato

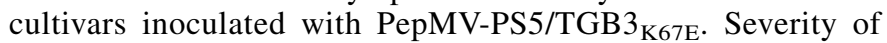
necrotic symptoms varied according to the environmental condition, being greater under condition I, and with the cultivar, Beta Lux and Moneymaker being the most susceptible ones. Necrosis occurred in the inoculated and systemic leaves as necrotic spots, mainly found near the edges of the leaves and necrosis alongside the central veins (Fig. 1C). Plants infected with PepMV-Sp13, PepMV-Sp13/TGB3 $3_{\text {K67E }}$, and PepMV-PS5 showed slight stunting compared with the mock-inoculated plants, but no necrosis. No tomato cultivar infected with PepMV-Sp13/TGB3 $3_{\text {K67E }}$ showed necrotic symptoms, even after 6 weeks postinoculation. RT-PCR and sequencing of the PepMV triple gene block using total RNA from PepMV-Sp13/TGB3 ${ }_{\text {K67E }}$-infected plants confirmed the stability of the introduced mutation, with no other mutation occurring in the sequenced region.

We performed a new experiment in which the most susceptible cultivars (Beta Lux and Moneymaker) were inoculated with PepMV-Sp13 and PepMV-Sp13/TGB $3_{\text {K67E }}$ and grown under constant 24 to $25^{\circ} \mathrm{C}$ and $16 \mathrm{~h}$ light. At $24 \mathrm{dpi}$, all plants inoculated with PepMV-Sp13/TGB3 ${ }_{\text {K67E }}$ displayed necrotic symptoms, and viral accumulation in these new conditions was two-fold higher than in conditions I or II (Supplementary Fig. S1; main effect of environment condition: $F_{2,2}=26.10, P<0.001$ ). These results strongly suggest that necrosis development associates with high virus titers, which in turn depend on the virus isolate, tomato cultivar and environmental conditions. Thus, amino acid substitution K67E in TGB3 appears to be necessary but not sufficient for systemic necrosis induction. A plausible explanation is that TGB3 is involved in determining necrosis by enhancing virus accumulation in PepMVinfected plants.

Biochemical, cellular, and gene expression characterization of the necrosis phenotype. To characterize the systemic necrosis induced in tomato by necrogenic PepMV isolates, biochemical features, cytopathological characteristics and gene expression patterns associated with cell death were analyzed. Moneymaker tomato plants were inoculated with the four PepMV isolates and kept in a growth chamber at a fixed temperature $\left(24\right.$ to $25^{\circ} \mathrm{C}, 16 \mathrm{~h}$ light). Six weeks after inoculation only plants infected with the necrogenic isolates showed necrosis (Fig. 2A). Since similar results were obtained with PepMV-Sp13/TGB3 ${ }_{\text {K67E }}$ and PepMV-PS5/ $\mathrm{TGB}_{\mathrm{K} 67 \mathrm{E}}$, as well as with PepMV-Sp13 and PepMV-PS5, in this section we will refer to them as necrogenic and wild-type isolates, respectively. Accumulation of reactive oxygen species (ROS; $\mathrm{H}_{2} \mathrm{O}_{2}$ and $\mathrm{O}_{2}^{-}$) was examined by staining symptomatic and asymptomatic systemically infected leaves. A characteristic brown color was detected in leaves infected with necrogenic isolates stained with diaminobenzidine (DAB), indicating $\mathrm{H}_{2} \mathrm{O}_{2}$ accumulation (Fig. 2A). Superoxide accumulation $\left(\mathrm{O}_{2}^{-}\right)$in leaves showing necrotic symptoms was also detected by staining with NBT (Fig. 2A). No $\mathrm{H}_{2} \mathrm{O}_{2}$ or $\mathrm{O}_{2}^{-}$accumulation was detected in leaves infected with wild-type isolates. The cytopathology induced by PepMV was studied using both light microscopy (LM) and TEM. Only necrogenic isolates caused significant damage to the cellular structures (Fig. 2B), which extended all along the whole tissue section and affected all cell types of the leaf including epidermis, palisade parenchyma, mesophyll, and vascular cells (Fig. 2B). On the contrary, wild-type isolates did not cause any obvious cellular damage, apart from the typical potexviral cytoplasmic inclusions (Rao et al. 1978), which were observed in this case (Fig. 2C). Necrogenic isolates induced similar cytoplasmic inclusions as wild-type isolates (Fig. 2C) but also important ultrastructural damages including mitochondrial swelling (Fig. 2D), shrinkage of the protoplast (Fig. 2C), plasma membrane rupture (Fig. 2E), cytoplasmic collapse (Fig. 2C, F), nuclear envelope disassembly, and chromatin condensation (Fig. 2F) as well as rupture of the tonoplast (Fig. 2G). Recently, the up-regulation of several oxylipin biosynthesis genes such as 9-LOX and $\alpha-D O X-1$ during compatible plant-virus interactions that led to systemic necrosis has been described (García-Marcos et al. 2013). Here, RT-qPCR gene expression analyses from plants infected with PepMV-Ps5 and mutant PepMV-Ps5/TGB3 ${ }_{\text {K67E }}$ showed that 9-LOX and $\alpha-D O X-1$ tomato homologs were induced in plants infected with a necrogenic isolate compared with plants inoculated with a wildtype isolate or mock-inoculated plants (Fig. $2 \mathrm{H}$ ).

Systemic necrosis can be reproduced in $N$. benthamiana, where it also associates with enhanced virus accumulation. N. benthamiana plants infected with PepMV-PS5 and PepMV-PS5/ TGB $3_{\mathrm{K} 67 \mathrm{E}}$ were analyzed as described above, and similar results were found. After 4 weeks postinoculation, only plants inoculated with PepMV-PS5/TGB3 ${ }_{\text {K67E }}$ showed systemic necrosis (Fig. 3A), with virus accumulation levels being almost tenfold higher in these plants than in plants inoculated with PepMV-PS5 (Fig. 3B). ROS production was detected in leaves infected with the necrogenic isolate (Fig. 3A). Neither $\mathrm{H}_{2} \mathrm{O}_{2}$ nor $\mathrm{O}_{2}{ }^{-}$accumulation was detected in leaves infected with the wild-type isolate. The cytopathology of infected $N$. benthamiana leaves was also studied using both LM and TEM. Damage caused by the necrogenic isolate extended through the whole tissue section and affected all cell types of the leaf 
(Supplementary Fig. S2A). TEM images revealed the same morphological features found in tomato, such as mitochondrial swelling (Fig. 3C), shrinkage of the protoplast (Fig. 3D), plasma membrane rupture (Figs. 3D and E), rupture of tonoplast (Fig. 3D) as well as nuclear envelope disassembly and chromatin condensation (Figs. 3F and G). Cytoplasmic inclusions were observed in leaves infected with the necrogenic as well as with the wild-type isolate. Moreover, in this host, the wild-type isolate induced the appearance of other cytopathological structures resembling the laminated inclusions (Fig. 3H) already described for the potexvirus cytopathology (Allison and Shalla 1974; Edwardson and Christie
1978). We also found structures resembling viral particles (Fig. 3I). Finally, the PepMV necrogenic isolate induced the expression of oxylipins (Fig. 3J). Therefore, $N$. benthamiana and tomato seem to respond similarly to PepMV.

The results in $N$. benthamiana also suggested that the induction of necrosis was correlated with enhanced virus accumulation (Fig. 3B). To assess whether a nonnecrogenic PepMV isolate can cause necrosis when accumulating at high levels, we coinfiltrated full-length agroinfectious clones of PepMV-Sp13 or PepMV-PS5 together with the $\mathrm{p} 19$ silencing suppressor. At 5 days postinfiltration necrotic spots appeared only in leaves co-agroinfiltrated with p19,

A

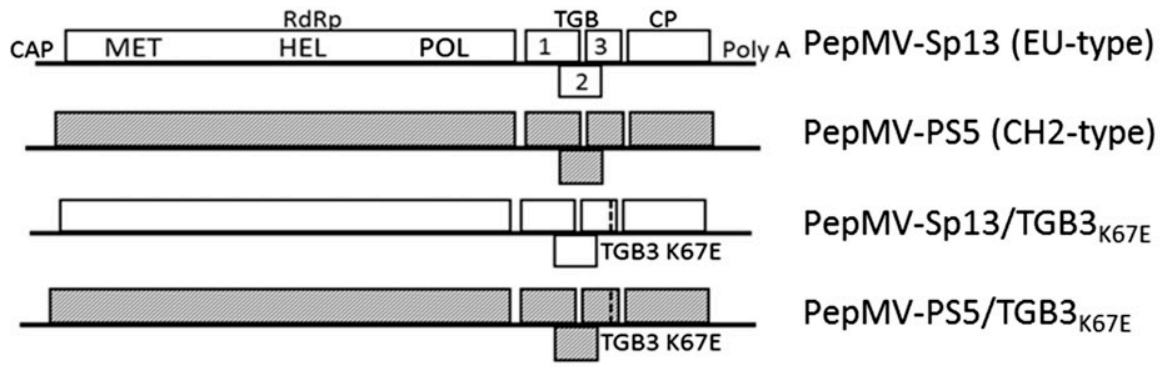

B
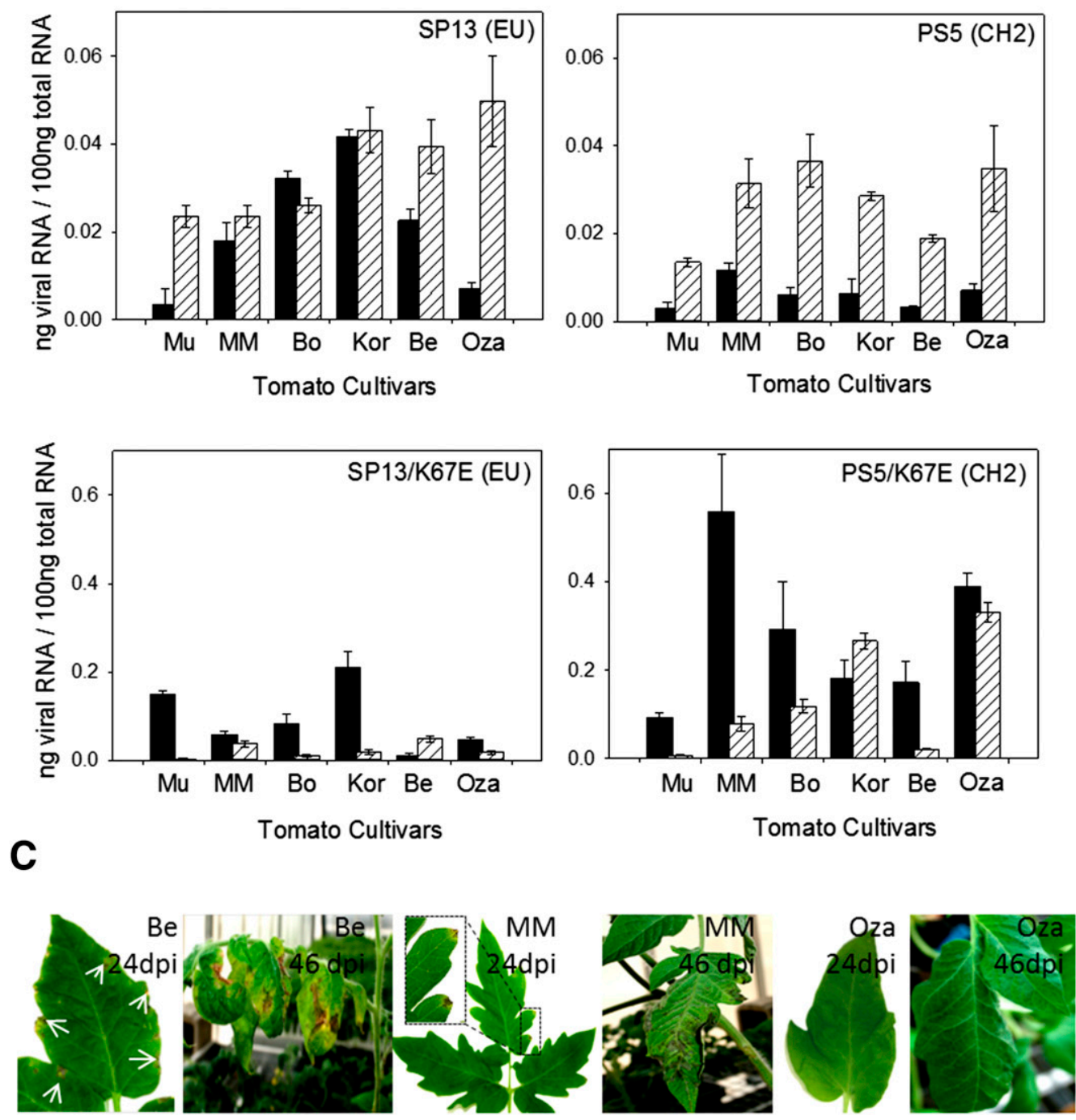

Fig. 1. Pepino mosaic virus (PepMV) systemic necrosis associates with enhanced virus accumulation. A, Schematic representation of PepMV isolates and mutants used in this work. B, PepMV accumulation levels (ng of viral RNA/100 ng of total RNA) in six different tomato varieties under two environmental conditions at 26 to $28^{\circ} \mathrm{C}$ day, 18 to $20^{\circ} \mathrm{C}$ night, and $16 \mathrm{~h}$ light (black bars) and at 21 to $22^{\circ} \mathrm{C}$ day, 15 to $16^{\circ} \mathrm{C}$ night, and $8 \mathrm{~h}$ light (striped bars). Tomato cultivars: Beta Lux (Be), Muchamiel (Mu), Boludo (Bo), Malinowy Ożarowski (Oza), Moneymaker (MM), and Koneser (Kon). C, Systemic necrosis in tomato (Be, MM, and Oza) at 24 and 46 days postinoculation. 
resembling the necrogenic response described above (showed for PepMV-Sp13 in Fig. 4A). DAB staining of agroinfiltrated leaves showed $\mathrm{H}_{2} \mathrm{O}_{2}$ production only in necrotic tissues (Fig. 4A). Moreover, PepMV-mediated necrosis in the presence of p19 was consistent with increased virus accumulation, as viral RNA accumulation in the agroinfiltrated leaves was almost 10-fold higher in the presence of $\mathrm{p} 19$ than in its absence (showed for PepMV-Sp13 in
Fig. 4B). These results strongly suggest that a nonnecrogenic isolate can cause necrosis when it reaches high accumulation levels.

Mapping of the necrosis elicitor in the PepMV genome. In order to map the necrosis elicitor in the viral genome, each PepMV gene was expressed into $N$. benthamiana leaves using pGWBs vectors (Nakagawa et al. 2007). PepMV-Sp13 and PepMV$\mathrm{Sp} 13 / \mathrm{TGB} 3_{\mathrm{K} 67 \mathrm{E}} \mathrm{cDNA}$ clones were used as PCR templates (Fig. 5).
A

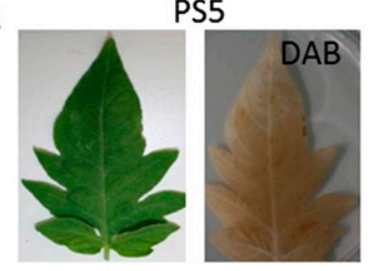

B

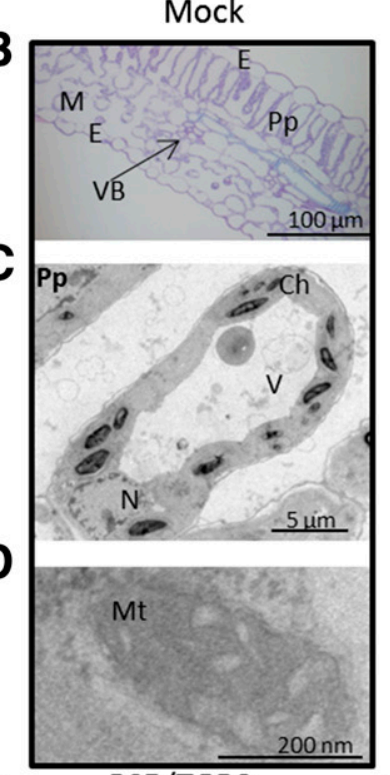

E

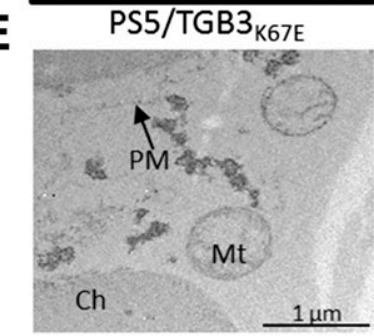

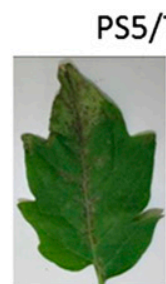
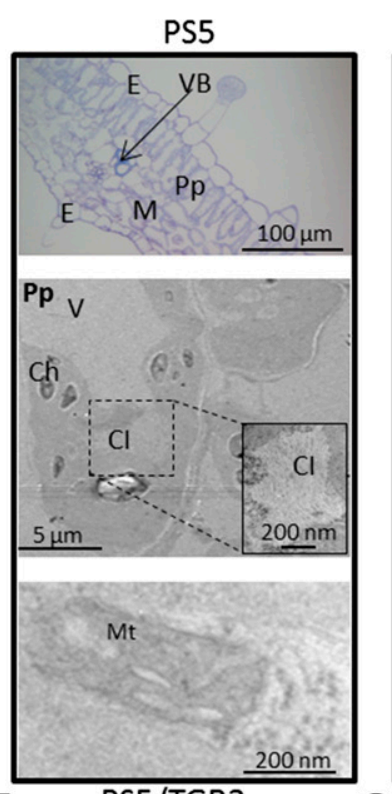

$\mathbf{F}$

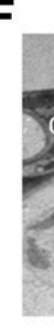

H

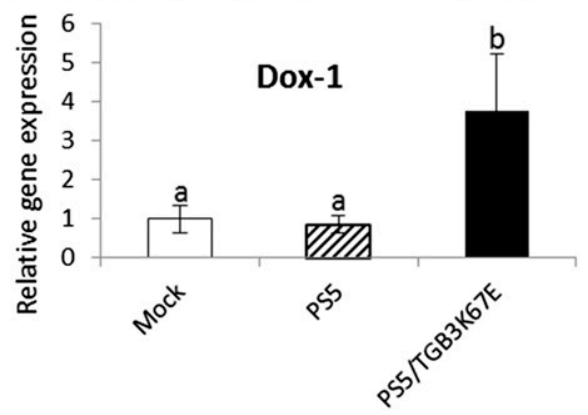

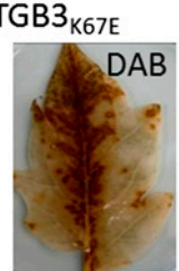

P5 5
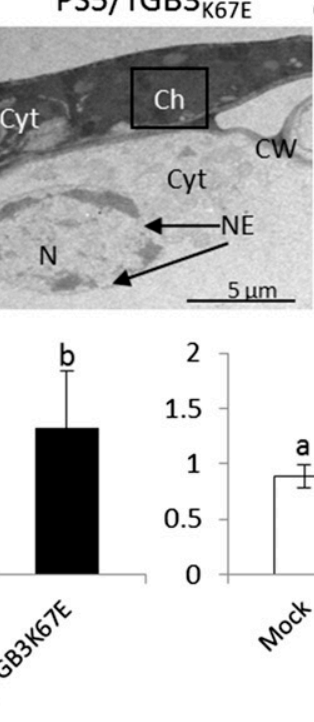

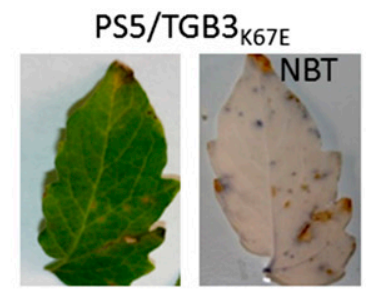

PS5/TGB3 ${ }_{\text {K67E }}$
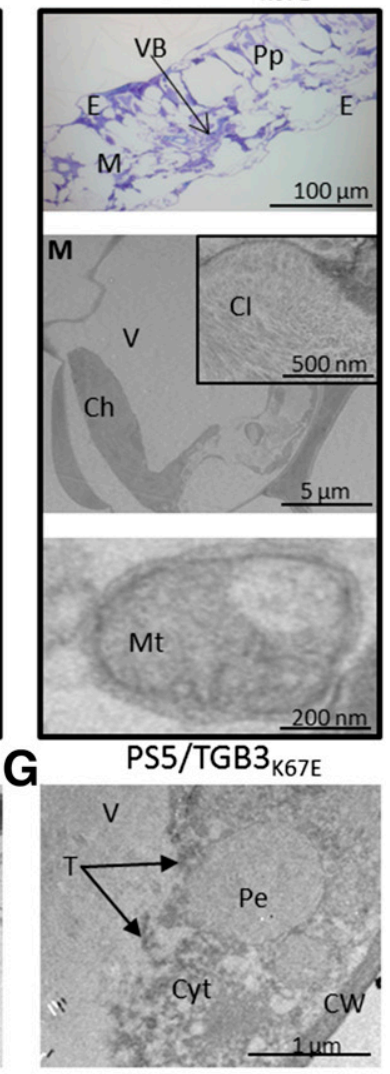

9-Lox
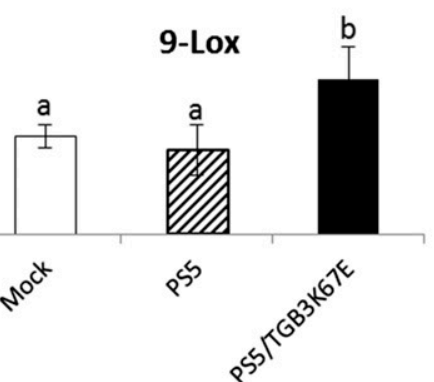

Fig. 2. Pepino mosaic virus (PepMV) systemic necrosis in tomato. A, Reactive oxygen species in tomato leaves systemically infected with PepMV-PS5 and PepMV-PS5/TGB3 $3_{\mathrm{K} 67 \mathrm{E}}$. The accumulation of $\mathrm{H}_{2} \mathrm{O}_{2}$ and $\mathrm{O}_{2}$ was analyzed by diaminobenzidine (DAB; deep brown color) and nitroblue tetrazolium (NBT; dark blue color) staining. B, Light microscopy images showing necrosis damage only in tomato tissues infected with the necrogenic isolate PS5/TGB3 $3_{\mathrm{K} 67 \mathrm{E} \text {. }} \mathbf{C}$ to $\mathbf{G}$, Transmission electron micrographs of transversal leaf sections showing cytopathological cytoplasmic inclusions (CI) and ultrastructural damages in tomato tissues infected with PS5/TGB3 ${ }_{\mathrm{K} 67 \mathrm{E}}$. C, Shrinkage of the protoplast. D, Mitochondria (Mt) swelling. E, Plasma membrane (PM) rupture. C and F, Cytoplasmic (Cyt) collapse. F, Nuclear envelope (NE) disassembly and chromatin (chr) condensation and G, rupture of the vacuolar tonoplast (T). Ch, chloroplast; CW, cell wall; E, epidermis; M, mesophyll; N, nucleus; Pp, palisade parenchyma; Pe, peroxisome; V, vacuole; and VB, vascular bundle. H, Relative RT-qPCR analysis of expression of the 9-LOX and DOX-1 genes in tomato leaves 40 days after inoculation. Data represent the mean standard errors of three replicates. Statistically significant differences were determined by Duncan's multiple range tests $(P$ value of 0.05$)$. 
For the $R d R p$ gene, three constructs were made, each containing a different domain conserved in the RdRp protein: MET (M), MET-HEL (MH), and polymerase (POL). For the TGB3, two versions were assayed, TGB3K and TGB3E, from -Sp13 and -Sp13/TGB3 $3_{\text {K67E }}$ clones, respectively. Agrobacterium tumefaciens cultures containing each construct were infiltrated with and without p19 in $N$. benthamiana, and leaves were monitored at 3 and 6 days after infiltration. No necrotic phenotype was observed with any construct when infiltrated in the absence of p19. Transient expression of both TGB3 versions, TGB3K and TGB3E, induced the same phenotype, which was visible at $3 \mathrm{dpi}$, consisting of faint vein necrosis resembling a cytotoxic effect. Importantly, POL domain expression triggered a characteristic necrosis phenotype at $5 \mathrm{dpi}$, clearly resembling the necrosis phenotype described above for inoculations with the whole virus construct.

Transient expression of PepMV-PS5 POL, and PepMV-PS5, or PepMV-PS5/TGB3 ${ }_{\text {K67E }}$ TGB3 reproduced the phenotypes described for PepMV-Sp13 and its mutant (data not shown). We also examined whether the POL-induced necrosis was caused by the expression of the protein or by the expression of the RNA coding for it. A frame shift mutation was introduced after the initiation codon in the POL construct to create POL-fs, preventing translation of the protein.
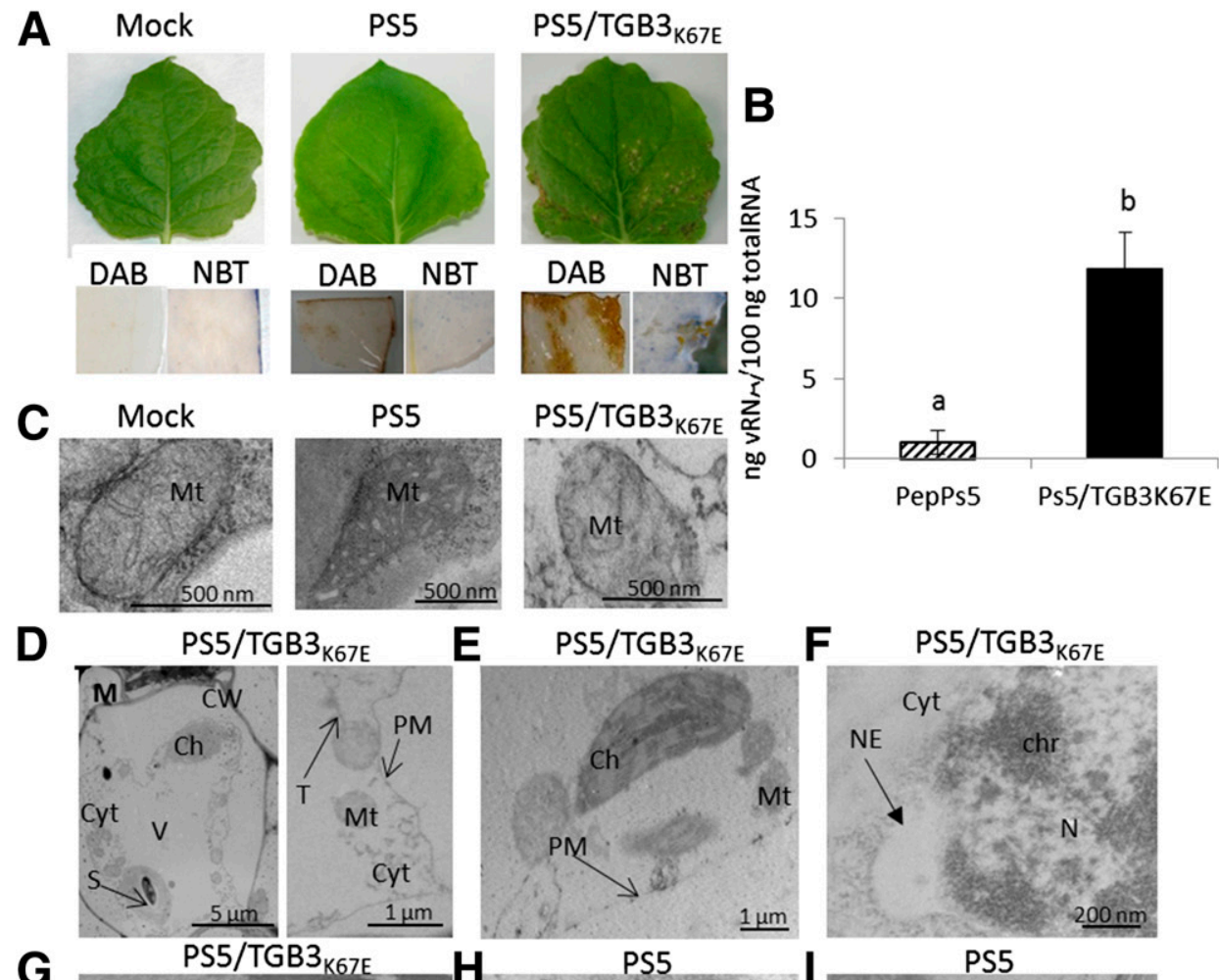

$\mathbf{G}$
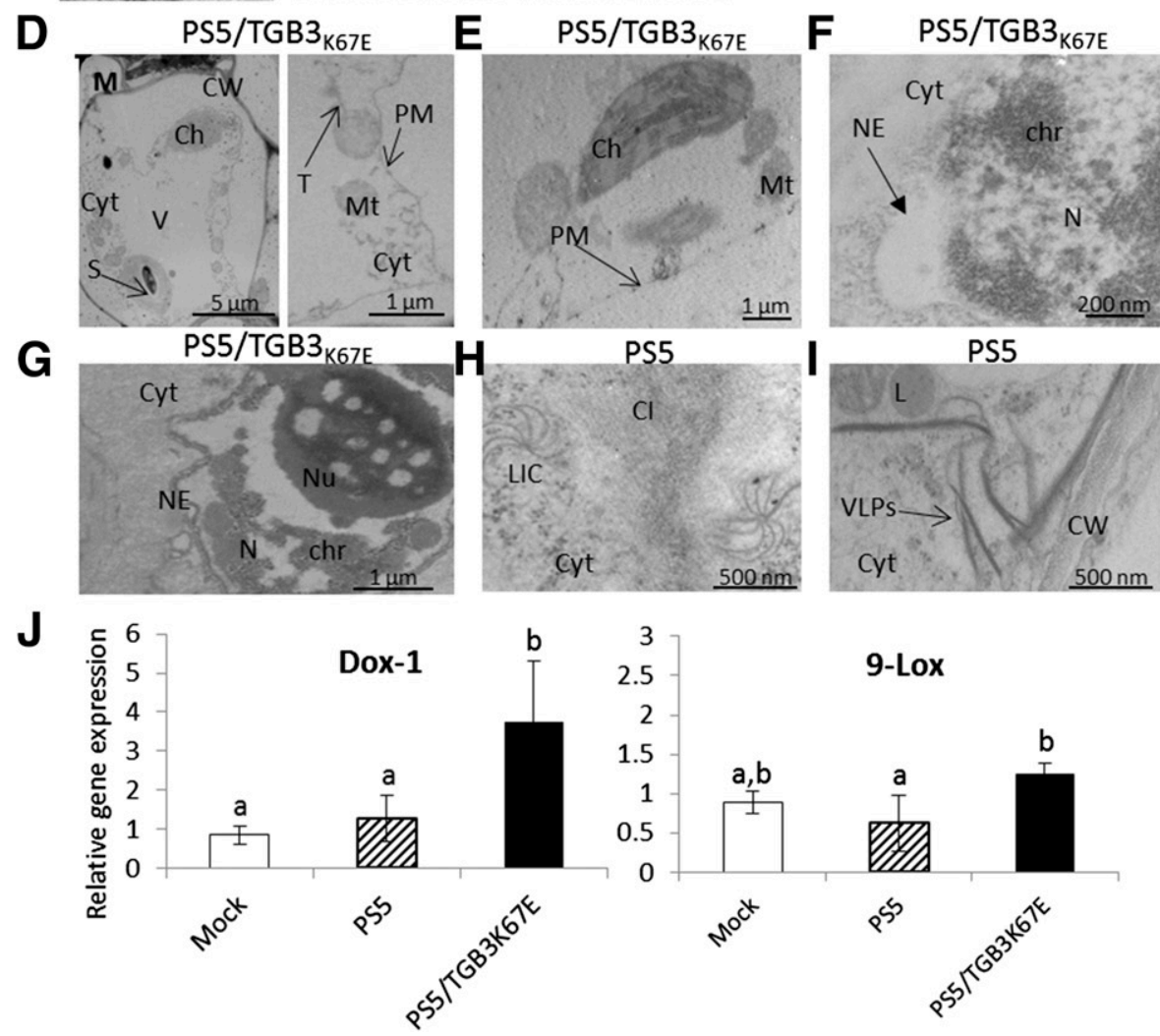

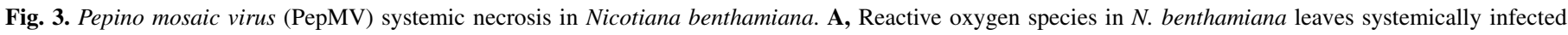

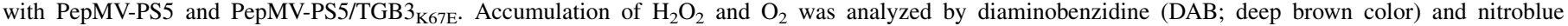

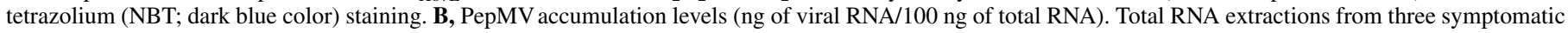

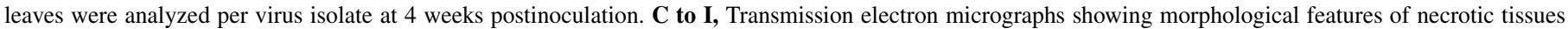

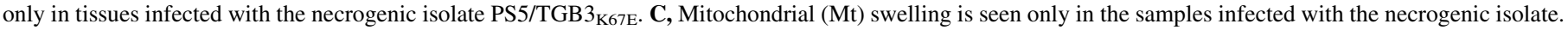

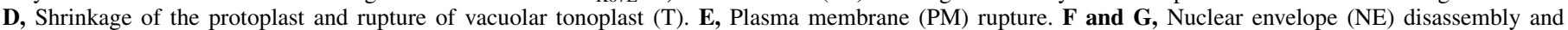

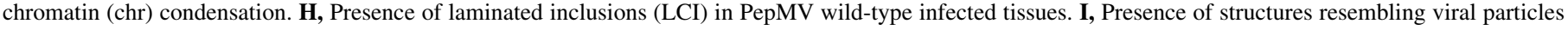

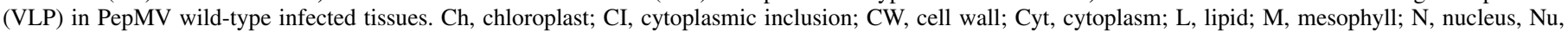

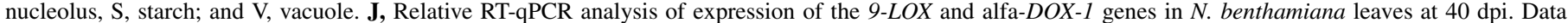
represent the mean standard errors of three replicates. Statistically significant differences were determined by Duncan's multiple range tests $(P$ value of 0.05$)$. 
Leaf areas infiltrated with $A$. tumefaciens cultures expressing POL-fs did not exhibit necrosis, independent of whether or not p19 was coexpressed (data not shown). Taken together, these results indicate that the POL domain of the RdRp encoded by both symptomatic and asymptomatic PepMV isolates is a necrosis-inducing elicitor.

POL-induced necrosis reproduced characteristics of the PepMV-induced necrosis. Since TGB3 has already been described as the PepMV necrosis genetic determinant (Hasiów-Jaroszewska et al. 2011) and, as shown above, its expression caused faint vein necrosis (Fig. 6A), our next analysis was performed in parallel for both, POL and TGB3, coexpressed with p19. $\mathrm{H}_{2} \mathrm{O}_{2}$ and $\mathrm{O}_{2}{ }^{-}$were clearly detected by DAB and NBT staining, respectively, in regions infiltrated with the construct expressing POL (Fig. 6A). In contrast, areas expressing TGB3 did not show signal after NBT staining and only slight brownish was detected after DAB staining, indicating low level or no ROS accumulation (Fig. 6A). In the presence of ascorbic acid, which is a $\mathrm{H}_{2} \mathrm{O}_{2}$ scavenger, the same brownish color in TGB3 infiltrated areas was still present, indicating that it was not due to $\mathrm{H}_{2} \mathrm{O}_{2}$ accumulation (Fig. 6A). These results show that only the POL domain expression triggers a phenotype resembling the one described for PepMV viral infection. Next, we analyzed oxylipin mRNA accumulation in $N$. benthamiana leaves expressing POL and TGB3 after agroinfiltration in the presence of $\mathrm{p} 19$. $\alpha$-DOX-1 mRNA accumulation was similarly increased in all treatments (data not shown). 9-LOX mRNA accumulation seemed to be higher for tissues infiltrated with POL+p19 cultures than for the other treatments, though there was no statistically significant difference compared with leaf areas infiltrated with TGB3+p19 cultures (Supplementary Fig. S3).

Data shown here indicate that the necrosis response induced either by PepMV infection or by POL expression shares fundamental characteristics of HR (Lam et al. 2001; Mur et al. 2008; Torres 2010; van Doorn et al. 2011). One of the hallmarks of HR is the activation of defense mechanisms that depend on the production of salicylic acid (SA), jasmonic acid (JA), and ethylene (Kim et al. 2008). Thus, we tested whether the prevention of SA or JA accumulation in $N$. benthamiana could inhibit or modify the development of the necrosis phenotype elicited by POL expression. For this, we performed agroinfiltrations with the PepMV constructs in $N a h G$

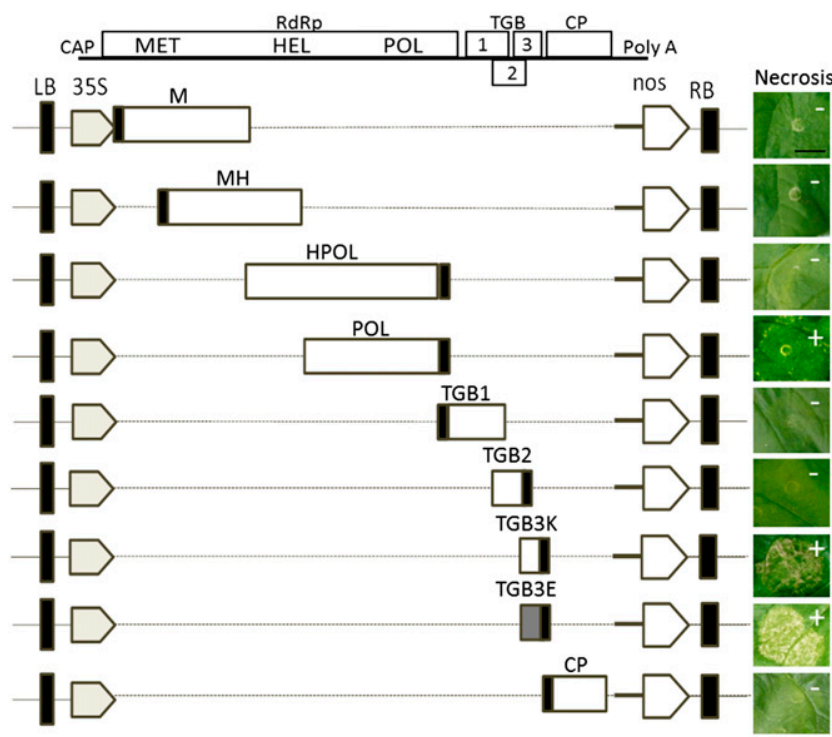

Fig. 5. Expression of POL and TGB 3 of different Pepino mosaic virus strains induce necrosis in Nicotiana benthamiana. Schematic representation of the PepMV-Sp13 constructs used for the separate transient expression of each PepMV protein (TGB1, 2, 3, and CP) or RdRp methyltransferase (M), methyltransferasehelicase $(\mathrm{MH})$, and polymerase (POL) domains in the presence of p19. Dark bars in the N-terminal region of constructs $\mathrm{M}, \mathrm{MH}$, TGB1, and $\mathrm{CP}$, and at the C-terminal region of constructs POL, TGB2, TGB3K, and TGB3E indicate the insertion of a His-tag for detection. The photos at the right show the agroinfiltrated region at 6 days postinoculation. Bars $=5 \mathrm{~mm}$.
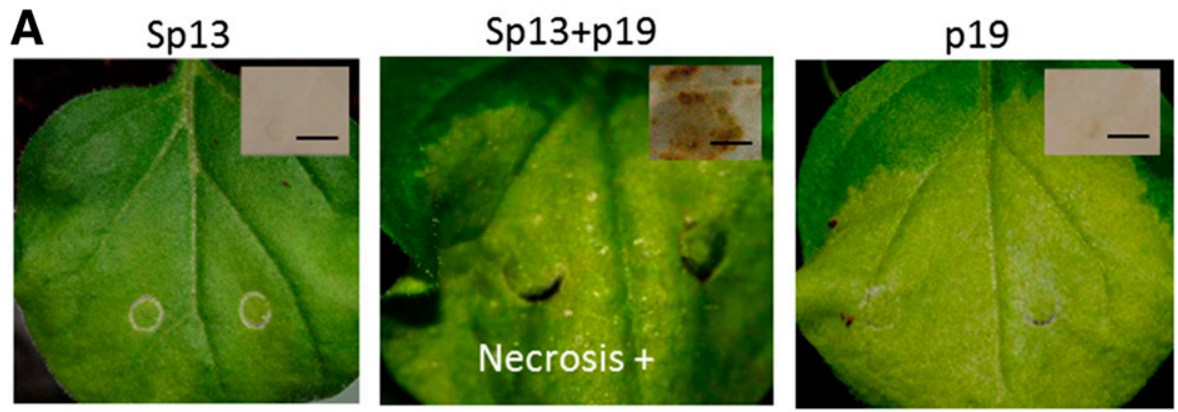

B

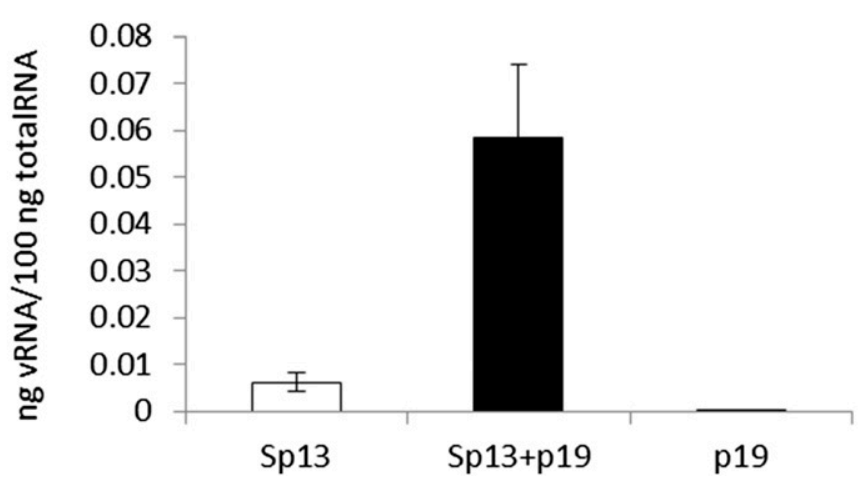

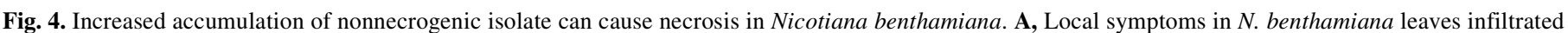

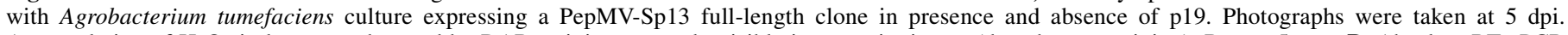

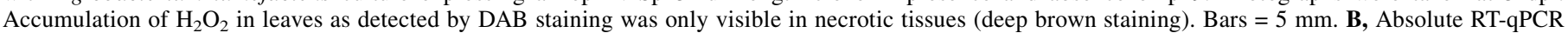

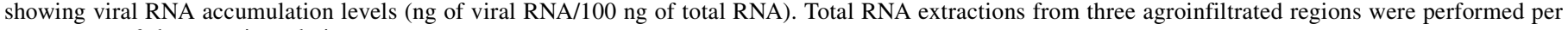
treatment at 6 days postinoculation. 
and $\mathrm{NbCOII}$ transgenic plants (in the presence of $\mathrm{p} 19$ ), which have altered SA and JA routes, respectively (Alamillo et al. 2006; Chini et al. 2009; García-Marcos et al. 2013). In NahG plants, expression of the POL domain displayed the same necrotic symptoms as in wild-type plants, indicating that SA does not mediate necrosis induced in $N$. benthamiana by POL. DAB staining confirmed the presence of ROS in POL-infiltrated areas (Fig. 6B). On the contrary, no necrosis was observed after infiltration of POL in $\mathrm{NbCOII}$ leaves, while no ROS accumulation was detected in $\mathrm{NbCOI1}$ POLinfiltrated areas. This result indicates that JA signaling pathway is essential for elicitation of the necrosis response by POL. The faint vein necrosis phenotype induced by TGB3 was insensitive to SA- or JA-signaling pathway alteration (Fig. 6B).

The polymerase domains of all RdRps share an overall structure that resembles a "cupped hand" and contains "fingers," "palm," and "thumb" domains (Fig. 7A). According to this model, we designed three new constructs for the separate transient expression of each of the three structural domains and $N$. benthamiana leaves were coinfiltrated with these constructs and p19. At $6 \mathrm{dpi}$, the transient expression of neither R3A nor R3C triggered necrosis, while the expression of the R3B domain, containing the palm domain, did (Fig. 7B). These results indicate that the $\mathrm{RdRp}$ region that elicits necrosis resides in the palm domain, which contains amino acids GDD (Fig. 7C), which are highly conserved among viral RdRps (Kamer and Argos 1984; Poch et al. 1990).

\section{DISCUSSION}

High levels of PepMV accumulation associate with necrosis development. Changing environmental conditions such as temperature can affect viral RNA replication (Aldaoud et al. 1989; Kaper et al. 1995; Király et al. 2008; Lim et al. 2010; White et al.
A

TGB3+ p19

B

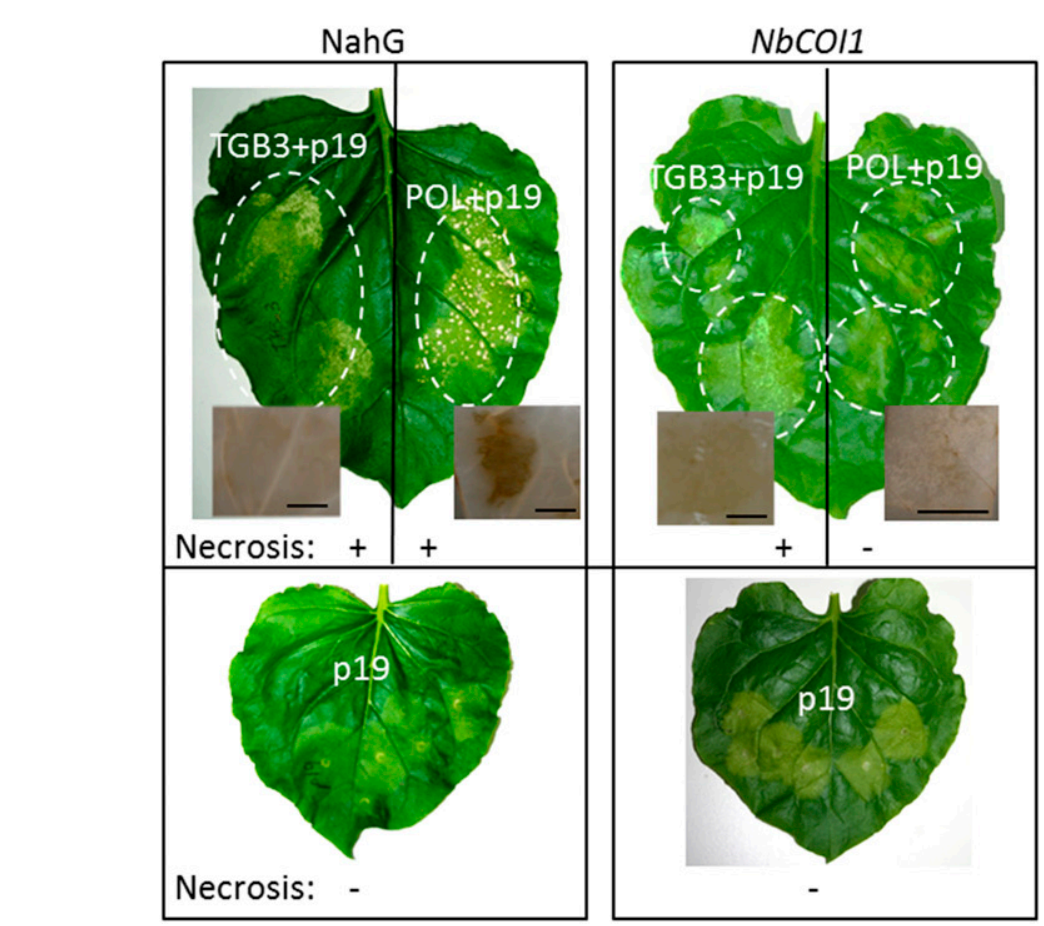

POL+p19
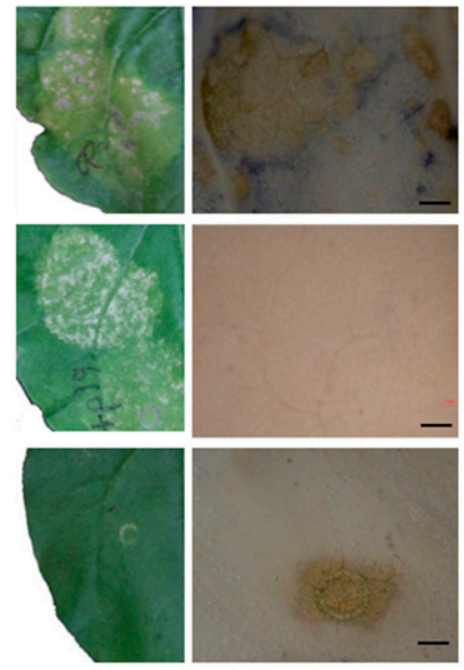

DAB $\quad \mathrm{DAB}+$ Ascorbic Acid
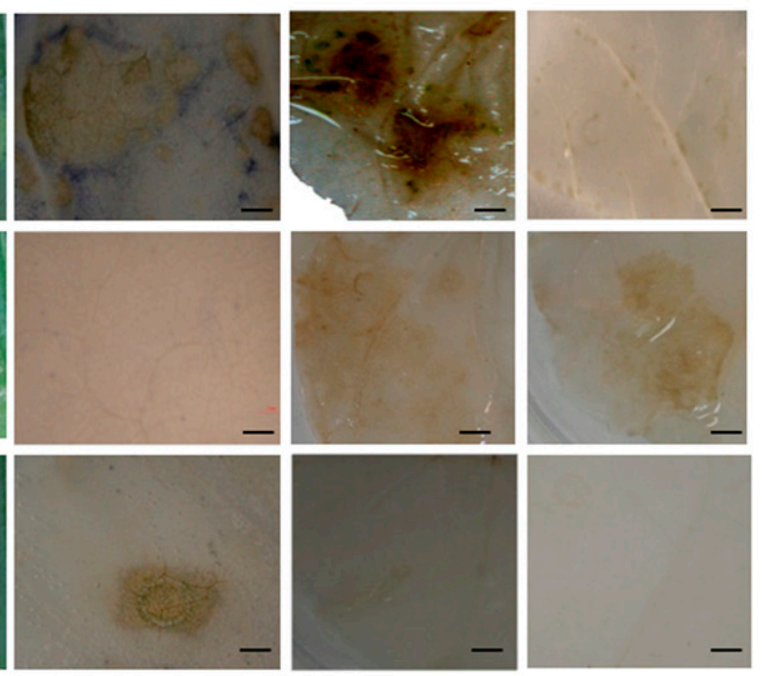

P19

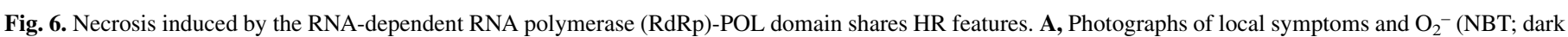

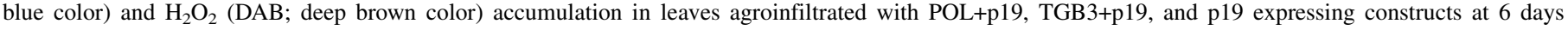

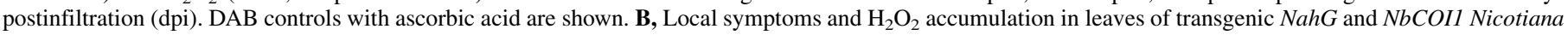

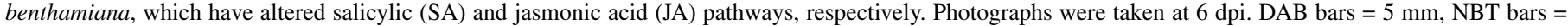
$1 \mathrm{~mm}$. 
1995) and the expression of necrotic reactions (Li et al. 2009; Wang et al. 2009; Whitham et al. 1996). Our results consistently showed that environmental factors affected PepMV accumulation levels and the development of necrosis. In our experiments, $\mathrm{CH} 2$ isolates appeared to be more responsive to temperature changes than EU isolates. In general, temperatures around $26^{\circ} \mathrm{C}$ enhanced the accumulation of isolates carrying the $\mathrm{TGB} 3_{\mathrm{K} 67 \mathrm{E}}$ mutation. At high $\left(>28^{\circ} \mathrm{C}\right)$ or low $\left(<21^{\circ} \mathrm{C}\right)$ temperatures, symptoms of necrosis were mild or did not even appear (data not shown). Temperatures greatly affect Alternanthera mosaic virus (AltMV; genus Potexvirus) accumulation, which correlates with increased necrotic symptoms (Lim et al. 2010). Our experiments suggested that the higher the viral titer, the more likely the development of necrosis. This was particularly evident with experiments involving PepMV-Sp13/TGB3 ${ }_{\mathrm{K} 67 \mathrm{E}}$
A

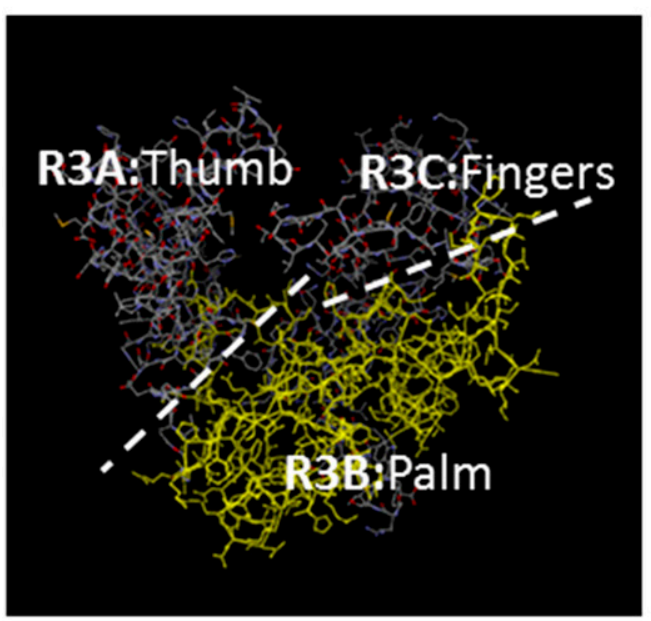

B

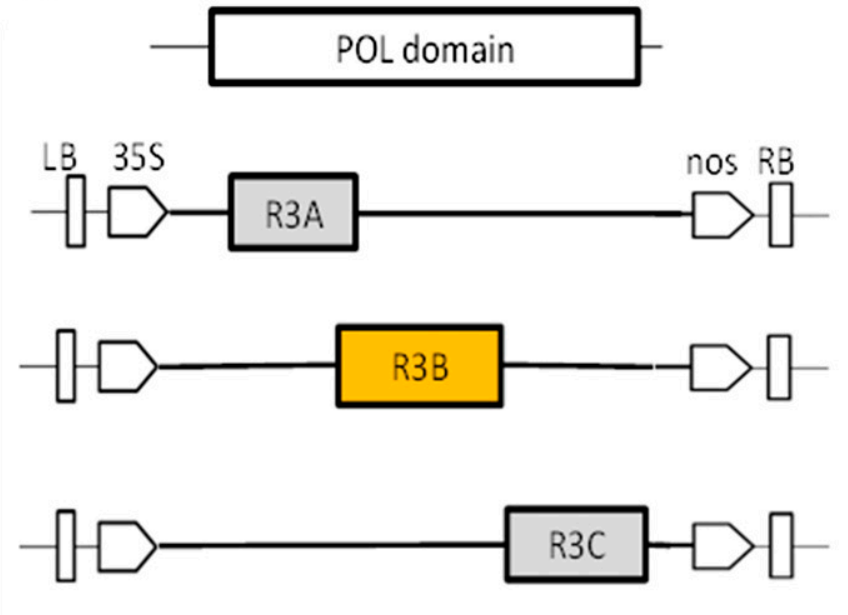

Necrosis

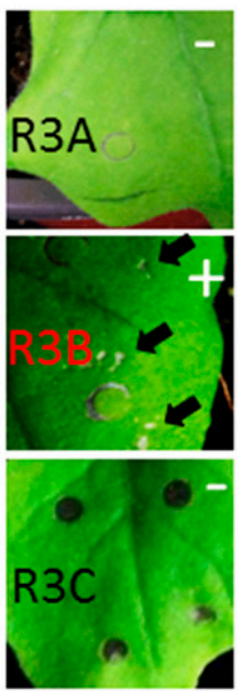

C

Sp13 TWEICAAEVKNTYLAKPMANLINAASRQSPDFDANKISLFLKSQWVKKVEKLGAVKSKPG 60

PS5 TWEICAAEVKNTYLAKPMANLINAASRQSPDFDSNKISLFLKSQWVKKVEKLGAIKSKPG 60

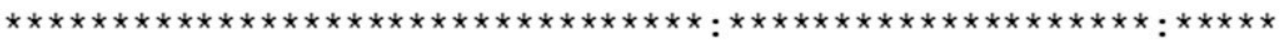

Sp13 QTIAAFMQQTVMLYGTMARYLRKMRQRFQPKHIFINCETTTDNLNQFVKQGWNENRTAQT 120

PS5 QTIAAFMQQTVMLYGTMARYLRKMRQRFQPKHIFINCETTTDDLNKEVKDGWNENRTAQT 120

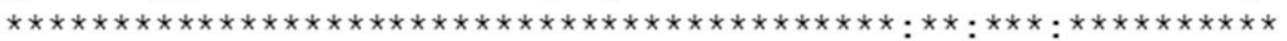

Sp13 NDFTAFDQSQDGAMLQFEVMKAKFFNIPADIIEGYINIKLNAKIFLGTLSIMRLSGEGPT 180

PS5 NDFTAFDQSQDGAMLQEEVMKAKFFNIPADVIEGYINIKLNAKIFLGTLSIMRLSGEGPT 180

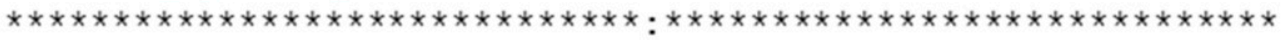

Sp13 EDANTECSIAYTATRYHLDSTVQVYAGDDMALDGVVQEKPSEKKLQNKLKLTSKTLFPK 240

PS5 FDANTECSIAYTATRFHIDNTVKQVYAGDDMALDGVVSEKKSERKLQNLLKLTSKTLYPK 240

$\star * * * * * * * * * * * * * *: *: * . * * * * * * * * * * * * * * * * * . * * * *: * * * * * * * * * * * *: * *$

Sp13 QVKGDYAEFCGWTFT PGGI IKNPLKMHASIMLQEAIGNLHTAARSYAIDMKHSYQMGDEL 300

PS5 QVKGDYAEFCGWTFTPGGI IKNPLKMHASIMLQEAIGNLHTAARSYAIDMKHSYQMGDQL 300

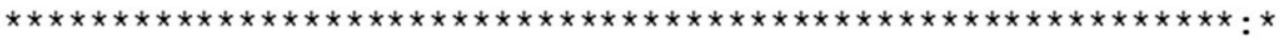

Sp13 HNYLTPDEAEQHFLAVRKLHKLHQGEAMRLGEKSP PKATH 340

PS5 HDYLTLDEAEQHFLAVRKLHKLHQGEAMRLGEKSPPRSTH 340

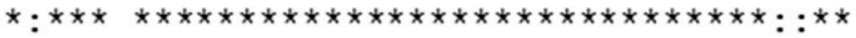

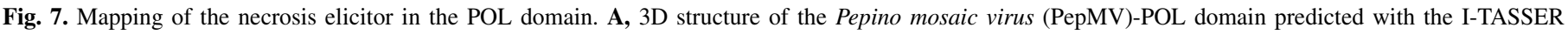

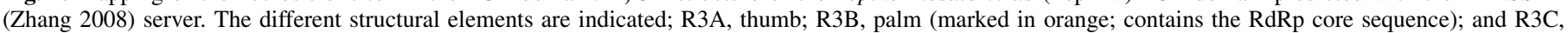

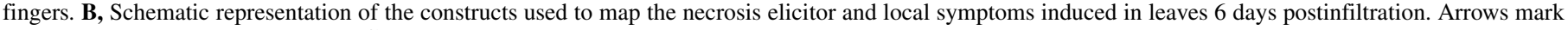

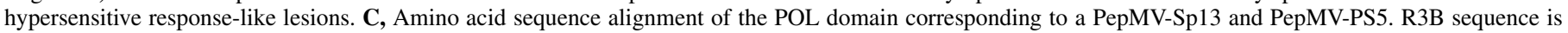

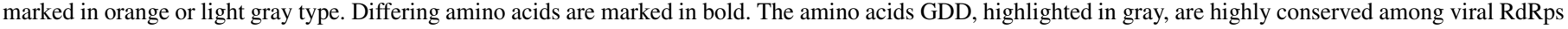
(Kamer and Argos 1984; Poch et al. 1990). 
and Beta Lux and Moneymaker, the two more susceptible cultivars: only when the environmental conditions favored high virus titers did systemic necrosis develop. In line with these results, we were able to induce local necrosis in $N$. benthamiana with a nonnecrogenic isolate by increasing virus accumulation through the presence of the silencing suppressor p19. This and the abovediscussed results strongly suggest that necrosis development depends on the viral titer.

Systemic necrosis induced by PepMV in tomato and in $N$. benthamiana share HR features. HR normally inhibits pathogen invasion, whereas systemic necrosis cannot, but both responses have similar phenotypic and molecular features (Dickman et al. 2001; Komatsu et al. 2010; Love et al. 2005; Xu and Roossinck 2000; Xu et al. 2004; Yao et al. 2002). The characterization of the PepMV-induced necrosis in tomato and in $N$. benthamiana revealed that similar processes take place in both hosts, showing that this response is not host specific. PepMV-induced necrosis included significant cellular alterations, such as ROS production and the induction of defense genes such as $9-L O X$ and $\alpha-D O X-1$, which are regulators of many defense pathways (Gao et al. 2008; García Marcos et al. 2013; Vellosillo et al. 2007). All of these changes are characteristic of HR, indicating that PepMV-induced necrosis shares HR features. Consistent with this observation, both ROS production and upregulation of oxylipin gene expression were reported during systemic necrosis in $N$. benthamiana induced by Potato virus $X$-Potato virus $Y$-associated synergism (García Marcos et al. 2013). Following the morphological classification of plant cell death made by van Doorn et al. (2011), the type of ultrastructural damage found in tomato and $N$. benthamiana tissues infected with necrogenic PepMV isolates had the characteristics of plant cell necrosis together with some of the characteristics of vacuolar cell death (van Doorn et al. 2011). Thus, cytopathological features of plant cell necrosis such as mitochondrial swelling or shrinkage of the protoplast were found in both hosts, together with features of vacuolar cell death such as rupture of the tonoplast or nuclear envelope disassembly.

The PepMV RdRp-POL domain elicits a HR-like response similar to that induced by the virus, whereas TGB3 does not. By transiently expressing the different PepMV proteins we have shown that PepMV POL elicits HR-like local lesions in $N$. benthamiana infiltrated leaves. Moreover, the overexpression of the POL domain from the nonnecrogenic PepMV-Sp13 along with p19 also induced HR-like local lesions, while expression in the absence of the p19 silencing suppressor did not induce necrotic lesions, suggesting that POL HR-inducing activity is dose-dependent. The expression of PepMV TGB3 also induced a phenotype of faint vein necrosis. The necrosis phenotypes induced by constructs expressing TGB3K and TGB3E were similar, indicating that the residue at position 67 was not its determinant. On the other hand, the absence of ROS accumulation showed that the overexpression of TGB3 does not trigger one of the most characteristic features of a HR. One of the explanations could be that PepMV TBG3 leads to a partially controlled unfolded protein response associated with faint necrosis, in agreement with data showing that PVX TGB3 overexpression in $N$. benthamiana triggers the unfolded protein response and SKP1-dependent programmed cell death (Ye et al. 2011). However, what is really relevant to our work is that the phenotype induced by overexpression of PepMV TGB3 does not resemble the HR-like systemic necrosis induced by the virus. Then, why has the amino acid at position 67 been mapped as a necrosis determinant? The impact of the amino acid substitution K67E on virus accumulation was higher than any other factor, and PepMV-induced necrosis appears to be dependent on the viral titer. This would suggest that TGB3 residue 67 may modulate viral accumulation perhaps by interacting with other viral and or host factors and, in turn, regulate the amount of the POL HR-like elicitor. Importantly, our findings have a remarkable parallelism with those obtained by Komatsu et al. (2011) for the potexvirus PlAMV, where an elicitor of systemic necrosis was identified in a genomic region separate from the previously mapped pathogenicity determinants (Komatsu et al. 2011). For another potexvirus, AltMV, not only did the polymerase domain and the upstream RdRp regions contribute to necrosis, but also a single residue in TGB1 had major effects on viral accumulation and necrosis (Lim et al. 2010).

Further characterization of the PepMV-POL induced necrosis. $N a h G$ transgenic plants infiltrated with the POL construct showed necrosis similar to that of wild-type $N$. benthamiana plants, suggesting that necrosis induced by POL is SA independent. Contrastingly, the absence of necrotic symptoms after infiltration of the POL construct in COII silenced plants suggested that the JA signaling pathway could be essential for elicitation of the necrosis response against POL. Taking into account that PepMV-induced necrosis is related with oxylipin gene expression, the variation of the necrotic response (in this case absence of necrosis) observed in $\mathrm{NbCOI1}$ plants expressing POL is coherent given the crucial participation of JA in the oxylipin signaling cascade. Alteration of the JA pathways can lead to the modification of the type of plant responses against pathogens, as shown by the silencing of $\mathrm{COII}$ in $N$. attenuata (ir-coil), which prevented the up-regulation of JA-mediated defenses and decreased the plant's resistance to herbivores and pathogens (Paschold et al. 2008). On the contrary, García-Marcos et al. (2013) reported a different situation; the systemic necrosis response caused by the synergistic interaction of Potato virus $X$-Potato virus $Y$ (which upregulates the oxylipin expression) was stronger and faster in $\mathrm{NbCOII}$ plants.

Our results indicated that the necrosis elicitor activity of POL resides in the central region of the structure, the palm domain, where the highly conserved GDD motif (Kamer and Argos 1984; Poch et al. 1990) is located. In the case of Cucumber mosaic virus (CMV), two amino acids of the 2a polymerase protein, at positions 631 and 641 that are in the vicinity of its GDD motif, have been reported as determinants of HR induction in cowpea plants (Kim and Palukaitis 1997). Amino acid substitutions at these positions allowed systemic infection to occur without HR and increased the accumulation of both the 2a polymerase protein and viral RNA in protoplasts. Moreover, it was shown that the GDD motif region of the $2 \mathrm{a}$ polymerase protein was also very important for interactions with the CMV movement protein (Hwang et al. 2007). Further experiments to explore if similar phenomena occur in PepMV are in progress in our laboratory.

In conclusion, by characterizing wild-type and mutant viruses we have shown that glutamic acid at position 67 of TGB3, previously described as a genetic determinant of necrosis (Hasiów-Jaroszewska and Borodynko 2012; Hasiów-Jaroszewska et al. 2011), is necessary but not sufficient for systemic necrosis induction. A strong association was found between virus accumulation levels and necrotic symptoms. In agreement with other studies on systemic necrosis, we demonstrated that systemic necrosis induced by PepMV in tomato and $N$. benthamiana share HR features (García-Marcos et al. 2013; Komatsu et al. 2011). The comparison of systemic necrosis induced in tomato and $N$. benthamiana in response to PepMV is important because it demonstrates that this response is not host specific. Moreover, we identified and mapped a strain-independent necrosis elicitor in the PepMV RdRp-POL domain. Its expression caused a similar necrotic response to that induced by whole-virus infection. On the other hand, TGB3 expression caused faint vein necrosis, a phenotype that was clearly different from that caused by virus infection, and this occurred independently of the TGB3 version expressed (wild-type or mutant). Thus, our results suggest that the PepMV-POL domain is an HR-like elicitor encoded by symptomatic and asymptomatic isolates, and that a POL expression threshold may exist beyond which further increases can induce necrosis. Altogether, our data suggest that PepMV necrosis induction depends on the virus accumulation level, which in turn may be modulated by the nature of TGB3 but also by other factors, including host genotype and environmental conditions. 


\section{ACKNOWLEDGMENTS}

Work was supported by grants AGL2012-37390 (Ministerio de Economía y Competitividad, Spain) and DEC-2011/01/D/NZ9/00279 (National Science Center, Poland). We thank J. A. Hernández, P. Díaz, L. Rodriguez-Moreno, and M. García for their technical assistance, $\mathrm{V}$. Truniger for critically reading the manuscript, and M. Fon for editorial assistance.

\section{LITERATURE CITED}

Aguilar, E., Almendral, D., Allende, L., Pacheco, R., Nam Chung, B., Canto, T., and Tenllado, F. 2015. The P25 protein of Potato virus $X$ (PVX) is the main pathogenicity determinant responsible for systemic necrosis in PVX-associated synergisms. J. Virol. 89:2090-2103.

Aguilar, J. M., Hernandez-Gallardo, M. D., Cenis, J. L., Lacasa, A., and Aranda, M. A. 2002. Complete sequence of the Pepino mosaic virus RNA genome. Arch. Virol. 147:2009-2015.

Alamillo, J. M., Saenz, P., and Garcia, J. A. 2006. Salicylic acid-mediated and RNA-silencing defense mechanisms cooperate in the restriction of systemic spread of Plum pox virus in tobacco. Plant J. 48:217-227.

Aldaoud, R., Dawson, W. O., and Jones, G. E. 1989. Rapid, random evolution of the genetic structure of replicating Tobacco mosaic virus populations. Intervirology 30:227-233

Allison, A. V., and Shalla, T. A. 1974. The ultrastructure of local lesions induced by Potato virus $X$ : A sequence of cytological events in the course of infection. Phytopathology 64:784-793.

Burgyán, J., Hornyik, C., Szittya, G., Silhavy, D., and Bisztray, G. 2000. The ORF1 products of tombusviruses play a crucial role in lethal necrosis of virus-infected plants. J. Virol. 74:10873-10881.

Chini, A., Boter, M., and Solano, R. 2009. Plant oxylipins: COI1/JAZs/MYC2 as the core jasmonic acid-signaling module. FEBS J. 276:4682-4692.

Díaz-Vivancos, P., Clemente-Moreno, M. J., Rubio, M., Olmos, E., García, J. A., Martínez-Gómez, P., and Hernández, J. A. 2008. Alteration in the chloroplastic metabolism leads to ROS accumulation in pea plants in response to Plum pox virus. J. Exp. Bot. 59:2147-2160.

Dickman, M. B., Park, Y. K., Oltersdorf, T., Li, W., Clemente, T., and French, R. 2001. Abrogation of disease development in plants expressing animal antiapoptotic genes. Proc. Natl. Acad. Sci. USA 98:6957-6962.

Duff-Farrier, C. R. A., Bailey, A. M., Boonham, N., and Foster, G. D. 2015. A pathogenicity determinant maps to the $\mathrm{N}$-terminal coat protein region of the Pepino mosaic virus genome. Mol. Plant Pathol. 16:308-315.

Edwardson, J. R., and Christie, R. G. 1978. Use of virus-induced inclusions in classification and diagnosis. Annu. Rev. Phytopathol. 16:31-55.

Ehrenfeld, N., Canon, P., Stange, C., Medina, C., and Arce-Johnson, P. 2005. Tobamovirus coat protein $\mathrm{CPCg}$ induces an HR-like response in sensitive tobacco plants. Mol. Cells 19:418-427.

Gao, X., Starr, J., Göbel, C., Engelberth, J., Feussner, I., Tumlinson, J., and Kolomiets, M. 2008. Maize 9-lipoxygenase ZmLOX3 controls development, root-specific expression of defense genes, and resistance to root-knot nematodes. Mol. Plant-Microbe Interact. 21:98-109.

García-Marcos, A., Pacheco, R., Manzano, A., Aguilar, E., and Tenllado, F. 2013. Oxylipin biosynthesis genes positively regulate programmed cell death during compatible infections with the synergistic pair Potato virus $X-$ Potato virus $Y$ and Tomato spotted wilt virus. J. Virol. 87:5769-5783.

Gómez, P., Sempere, R., and Aranda, M. A. 2012. Pepino mosaic virus and Tomato torrado virus: Two emerging viruses affecting tomato crops in the Mediterranean Basin. Adv. Virus Res. 84:505-532.

Gómez, P., Sempere, R., Elena, S., and Aranda, M. A. 2009. Mixed infections of Pepino mosaic virus strains modulate the evolutionary dynamics of this emergent virus. J. Virol. 83:12378-12387.

Gosálvez-Bernal, B., Genoves, A., Antonio Navarro, J., Pallas, V., and Sanchez-Pina, M. A. 2008. Distribution and pathway for phloem-dependent movement of Melon necrotic spot virus in melon plants. Mol. Plant Pathol. 9:447-461

Hajimorad, M. R., Eggenberger, A. L., and Hill, J. H. 2005. Loss and gain of elicitor function of Soybean mosaic virus G7 provoking Rsv1mediated lethal systemic hypersensitive response maps to P3. J. Virol. 79:1215-1222.

Hanssen, I., Paeleman, A., Wittemans, L., Goen, K., Lievens, B., Bragard, C., Vanachter, A., and Thomma, B. 2008. Genetic characterization of Pepino mosaic virus isolates from Belgian greenhouse tomatoes reveals genetic recombination. Eur. J. Plant Pathol. 121:131-146.

Hanssen, I., and Thomma, B. 2010. Pepino mosaic virus: a successful pathogen that rapidly evolved from emerging to endemic in tomato crops. Mol. Plant Pathol. 11:179-189.

Hanssen, I. M., Paeleman, A., Vandewoestijne, E., Van Bergen, L., Bragard, C., Lievens, B., Vanachter, A. C. R. C., and Thomma, B. P. H. J. 2009.
Pepino mosaic virus isolates and differential symptomatology in tomato. Plant Pathol. 58:450-460.

Hanssen, I. M., Peter van Esse, H., Ballester, A.-R., Hogewoning, S. W., Parra, N. O., Paeleman, A., Lievens, B., Bovy, A. G., and Thomma, B. P. H. J. 2011. Differential tomato transcriptomic responses induced by Pepino mosaic virus isolates with differential aggressiveness. Plant Physiol. 156:301-318.

Hasiów-Jaroszewska, B., and Borodynko, N. 2012. Characterization of the necrosis determinants of the European genotype of Pepino mosaic virus by site specific mutagenesis of an infectious cDNA clone. Arch. Virol. 157: 337-341.

Hasiów-Jaroszewska, B., Borodynko, N., Jackowiak, P., Figlerowicz, M., and Pospieszny, H. 2011. Single mutation converts mild pathotype of the Pepino mosaic virus into necrotic one. Virus Res. 159:57-61.

Hasiów-Jaroszewska, B., Jackowiak, P., Borodynko, N., Figlerowicz, M., and Pospieszny, H. 2010. Quasispecies nature of Pepino mosaic virus and its evolutionary dynamics. Virus Genes 41:260-267.

Hasiów-Jaroszewska, B., Paeleman, A., Ortega-Parra, N., Borodynko, N., Minicka, J., Czerwoniec, A., Thomma, B. P. H. J., and Hanssen, I. M. 2013. Ratio of mutated versus wild-type coat protein sequences in Pepino mosaic virus determines the nature and severity of yellowing symptoms on tomato plants. Mol. Plant Pathol. 14:923-933.

Hasiów-Jaroszewska, B., Pospieszny, H., and Borodynko, N. 2009. New necrotic isolates of Pepino mosaic virus representing the $\mathrm{Ch} 2$ genotype. J. Phytopathol. 157:494-496.

Hwang, M. S., Kim, K. N., Lee, J. H., and Park, Y. I. 2007. Identification of amino acid sequences determining interaction between the Cucumber mosaic virus-encoded 2 a polymerase and 3 a movement proteins. J. Gen. Virol. 88:3445-3451.

Kagiwada, S., Yamaji, Y., Komatsu, K., Takahashi, S., Mori, T., Hirata, H., Suzuki, M., Ugaki, M., and Namba, S. 2005. A single amino acid residue of RNA-dependent RNA polymerase in the Potato virus $X$ genome determines the symptoms in Nicotiana plants. Virus Res. 110:177-182.

Kamer, G., and Argos, P. 1984. Primary structural comparison of RNAdependent polymerases from plant, animal and bacterial viruses. Nucleic Acids Res. 12:7269-7282.

Kaper, J. M., Geletka, L. M., Wu, G. S., and Tousignant, M. E. 1995. Effect of temperature on Cucumber mosaic virus satellite-induced lethal tomato necrosis is helper virus strain dependent. Arch. Virol. 140:65-74.

Kim, B., Masuta, C., Matsuura, H., Takahashi, H., and Inukai, T. 2008. Veinal necrosis induced by Turnip mosaic virus infection in arabidopsis is a form of defense response accompanying HR-like cell death. Mol. Plant-Microbe Interact. 21:260-268.

Kim, C. H., and Palukaitis, P. 1997. The plant defense response to Cucumber mosaic virus in cowpea is elicited by the viral polymerase gene and affects virus accumulation in single cells. EMBO J. 16:4060-4068.

Király, L., Hafez, Y. M., Fodor, J., and Király, Z. 2008. Suppression of tobacco mosaic virus-induced hypersensitive-type necrotization in tobacco at high temperature is associated with downregulation of NADPH oxidase and superoxide and stimulation of dehydroascorbate reductase. J. Gen. Virol. 89:799-808.

Komatsu, K., Hashimoto, M., Maejima, K., Shiraishi, T., Neriya, Y., Miura, C., Minato, N., Okano, Y., Sugawara, K., Yamaji, Y., and Namba, S. 2011. A necrosis-inducing elicitor domain encoded by both symptomatic and asymptomatic Plantago asiatica mosaic virus isolates, whose expression is modulated by virus replication. Mol. Plant-Microbe Interact. 24:408-420.

Komatsu, K., Hashimoto, M., Ozeki, J., Yamaji, Y., Maejima, K., Senshu, H., Himeno, M., Okano, Y., Kagiwada, S., and Namba, S. 2010. Viral-induced systemic necrosis in plants involves both programmed cell death and the inhibition of viral multiplication, which are regulated by independent pathways. Mol. Plant-Microbe Interact. 23:283-293.

Lam, E., Kato, N., and Lawton, M. 2001. Programmed cell death, mitochondria and the plant hypersensitive response. Nature 411:848-853.

Li, D., Chen, P., Shi, A., Shakiba, E., Gergerich, R., and Chen, Y. 2009. Temperature affects expression of symptoms induced by Soybean mosaic virus in homozygous and heterozygous plants. J. Hered. 100:348-354.

Lim, H.-S., Nam, J., Seo, E.-Y., Nam, M., Vaira, A. M., Bae, H., Jang, C.-Y., Lee, C. H., Kim, H. G., Roh, M., and Hammond, J. 2014. The coat protein of Alternanthera mosaic virus is the elicitor of a temperature-sensitive systemic necrosis in Nicotiana benthamiana, and interacts with a host boron transporter protein. Virology 452-453:264-278.

Lim, H. S., Vaira, A. M., Reinsel, M. D., Bae, H., Bailey, B. A., Domier, L. L., and Hammond, J. 2010. Pathogenicity of Alternanthera mosaic virus is affected by determinants in RNA-dependent RNA polymerase and by reduced efficacy of silencing suppression in a movement-competent TGB1. J. Gen. Virol. 91:277-287.

Love, A. J., Yun, B. W., Laval, V., Loake, G. J., and Milner, J. J. 2005. Cauliflower mosaic virus, a compatible pathogen of Arabidopsis, engages three distinct defense-signaling pathways and activates rapid systemic generation of reactive oxygen species. Plant Physiol. 139:935-948. 
Mathioudakis, M. M., Rodriguez, L. M., Sempere, R. N., Aranda, M. A., and Livieratos, I. 2014. Multifaceted capsid proteins: Multiple interactions suggest multiple roles for Pepino mosaic virus capsid protein. Mol. Plant-Microbe Interact. 27:1356-1369.

Moreno-Pérez, M. G., Pagán, I., Aragón-Caballero, L., Cáceres, F., Fraile, A., and García-Arenal, F. 2014. Ecological and genetic determinants of Pepino mosaic virus emergence. J. Virol. 88:3359-3368.

Mur, L. A. J., Kenton, P., Lloyd, A. J., Ougham, H., and Prats, E. 2008. The hypersensitive response; the centenary is upon us but how much do we know? J. Exp. Bot. 59:501-520.

Nakagawa, T., Kurose, T., Hino, T., Tanaka, K., Kawamukai, M., Niwa, Y., Toyooka, K., Matsuoka, K., Jinbo, T., and Kimura, T. 2007. Development of series of gateway binary vectors, pGWBs, for realizing efficient construction of fusion genes for plant transformation. J. Biosci. Bioeng. 104:34-41.

Ozeki, J., Takahashi, S., Komatsu, K., Kagiwada, S., Yamashita, K., Mori, T., Hirata, H., Yamaji, Y., Ugaki, M., and Namba, S. 2006. A single amino acid in the RNA-dependent RNA polymerase of Plantago asiatica mosaic virus contributes to systemic necrosis. Arch. Virol. 151:2067-2075.

Pallas, V., and García, J. A. 2011. How do plant viruses induce disease? Interactions and interference with host components. J. Gen. Virol. 92: 2691-2705.

Paschold, A., Bonaventure, G., Kant, M. R., and Baldwin, I. T. 2008. Jasmonate perception regulates jasmonate biosynthesis and JA-Ile metabolism: The case of COI1 in Nicotiana attenuata. Plant Cell Physiol. 49:1165-1175.

Poch, O., Blumberg, B. M., Bougueleret, L., and Tordo, N. 1990. Sequence comparison of five polymerases (1 proteins) of unsegmented negative-strand RNA viruses: Theoretical assignment of functional domains. J. Gen. Virol. 71:1153-1162

Rao, D. V., Shukla, P., and Hiruki, C. 1978. In situ reaction of Clover yellow mosaic virus (CYMV) inclusion bodies with fluorescent antibodies to CYMV. Phytopathology 68:1156-1159.

Roggero, P., Lisa, V., Nervo, G., and Pennazio, S. 1996. Continuous high temperature can break the hypersensitivity of Capsicum chinense 'PI152225' to Tomato spotted wilt tospovirus (TSWV). Phytopathol. Mediterr. 35: 117-120.

Sempere, R., Gomez, P., Truniger, V., and Aranda, M. A. 2011. Development of expression vectors based on Pepino mosaic virus. Plant Methods 7:6.

Seo, J.-K., Lee, S.-H., and Kim, K.-H. 2009. Strain-specific cylindrical inclusion protein of Soybean mosaic virus elicits extreme resistance and a lethal systemic hypersensitive response in two resistant soybean cultivars. Mol. Plant-Microbe Interact. 22:1151-1159.

Soler, S., and Nuez, F. 2000. Identificación de fuentes de resistencia en tomate al Virus del mosaico del pepino dulce (PepMV). Page 199 in: X Congreso de la Sociedad Española de Fitopatología, Valencia.

Soler-Aleixandre, S., Lopez, C., Diez, M. J., de Castro, A. P., and Nuez, F. 2005. Association of Pepino mosaic virus with tomato collapse. J. Phytopathol. 153:464-469.
Torres, M. A. 2010. ROS in biotic interactions. Physiol. Plant. 138:414-429. van der Vlugt, R. A. A., Stijger, C. C. M. M., Verhoeven, J. T. J., and Lesemann, D. E. 2000. First report of Pepino mosaic virus on tomato. Plant Dis. $84: 103$.

van Doorn, W. G., Beers, E. P., Dangl, J. L., Franklin-Tong, V. E., Gallois, P., Hara-Nishimura, I., Jones, A. M., Kawai-Yamada, M., Lam, E., Mundy, J., Mur, L. A. J., Petersen, M., Smertenko, A., Taliansky, M., Van Breusegem, F., Wolpert, T., Woltering, E., Zhivotovsky, B., and Bozhkov, P. V. 2011. Morphological classification of plant cell deaths. Cell Death Differ. 18: 1241-1246.

Vellosillo, T., Martínez, M., López, M. A., Vicente, J., Cascón, T., Dolan, L., Hamberg, M., and Castresana, C. 2007. Oxylipins produced by the 9-Lipoxygenase pathway in Arabidopsis regulate lateral root development and defense responses through a specific signaling cascade. Plant Cell 19: 831-846.

Wang, Y., Bao, Z., Zhu, Y., and Hua, J. 2009. Analysis of temperature modulation of plant defense against biotrophic microbes. Mol. Plant-Microbe Interact. 22:498-506.

Werkman, A. W., and Sansford, C. E. 2010. Pest risk analysis for Pepino mosaic virus for the EU. Deliverable Report 4.3. EU Sixth Framework Project. Project PEPEIRA. http://www.wageningenur.nl/en/Expertise-Services/ Research-Institutes/plant-research-international/Pepeira.htm

White, J. L., Tousignant, M. E., Geletka, L. M., and Kaper, J. M. 1995. The replication of a necrogenic Cucumber mosaic virus satellite is temperature-sensitive in tomato. Arch. Virol. 140:53-63.

Whitham, S., McCormick, S., and Baker, B. 1996. The $N$ gene of tobacco confers resistance to Tobacco mosaic virus in transgenic tomato. Proc. Natl. Acad. Sci. USA 93:8776-8781.

Xu, P., Blancaflor, E. B., and Roossinck, M. J. 2003. In spite of induced multiple defense responses, tomato plants infected with Cucumber mosaic virus and D satellite RNA succumb to systemic necrosis. Mol. Plant-Microbe Interact. 16:467-476

$\mathrm{Xu}$, P., Rogers, S. J., and Roossinck, M. J. 2004. Expression of antiapoptotic genes bcl-xL and ced-9 in tomato enhances tolerance to viralinduced necrosis and abiotic stress. Proc. Natl. Acad. Sci. USA 101: $15805-15810$

Xu, P., and Roossinck, M. J. 2000. Cucumber mosaic virus D satellite RNA-induced programmed cell death in tomato. Plant Cell 12:10791092.

Yao, N., Imai, S., Tada, Y., Nakayashiki, H., Tosa, Y., Park, P., and Mayama, S. 2002. Apoptotic cell death is a common response to pathogen attack in oats. Mol. Plant-Microbe Interact. 15:1000-1007.

Ye, C., Dickman, M. B., Whitham, S. A., Payton, M., and Verchot, J. 2011. The unfolded protein response is triggered by a plant viral movement protein. Plant Physiol. 156:741-755.

Zhang, Y. 2008. I-TASSER server for protein 3D structure prediction. BMC Bioinform. 9:40. 